\title{
Malaria during Pregnancy
}

\author{
Michal Fried and Patrick E. Duffy \\ Laboratory of Malaria Immunology and Vaccinology, NIAID, NIH, Bethesda, MD 20892 \\ Correspondence: michal.fried@nih.gov; duffype@niaid.nih.gov
}

One hundred and twenty-five million women in malaria-endemic areas become pregnant each year (see Dellicour et al. PLoS Med 7: e1000221 [2010]) and require protection from infection to avoid disease and death for themselves and their offspring. Chloroquine prophylaxis was once a safe approach to prevention but has been abandoned because of drugresistant parasites, and intermittent presumptive treatment with sulfadoxine-pyrimethamine, which is currently used to protect pregnant women throughout Africa, is rapidly losing its benefits for the same reason. No other drugs have yet been shown to be safe, tolerable, and effective as prevention for pregnant women, although monthly dihydroartemisinin-piperaquine has shown promise for reducing poor pregnancy outcomes. Insecticide-treated nets provide some benefits, such as reducing placental malaria and low birth weight. However, this leaves a heavy burden of maternal, fetal, and infant morbidity and mortality that could be avoided. Women naturally acquire resistance to Plasmodium falciparum over successive pregnancies as they acquire antibodies against parasitized red cells that bind chondroitin sulfate $A$ in the placenta, suggesting that a vaccine is feasible. Pregnant women are an important reservoir of parasites in the community, and women of reproductive age must be included in any elimination effort, but several features of malaria during pregnancy will require special consideration during the implementation of elimination programs.

$P^{r}$ egnant women and women of childbearing age will require special consideration during mass campaigns for malaria elimination. Malaria susceptibility increases during pregnancy, making these women an important parasite reservoir in the community. Meanwhile, the biology and clinical presentations of Plasmodium falciparum in semi-immune women interfere with diagnosis during pregnancy, rendering targeted interventions ineffective for control (Fig. 1). Furthermore, concerns for teratogenicity and embryotoxicity complicate the proposed application of any drugs, vaccines, or antivector measures among women of reproductive age, greatly hindering mass campaign planning. For example, primaquine is the leading drug being assessed as a gametocytocidal agent to block parasite transmission to mosquitoes, but is contraindicated in pregnancy because the glucose-6-phosphate dehydrogenase status and hence hemolysis risk of the fetus would be unknown. This chapter reviews malaria during pregnancy, including its epidemiology and disease burden, molecular pathogenesis, naturally acquired immunity and potential for vaccines, diagnostic dilemmas, and drugs being used or

Editors: Dyann F. Wirth and Pedro L. Alonso

Additional Perspectives on Malaria: Biology in the Era of Eradication available at www.perspectivesinmedicine.org

Copyright (C) 2017 Cold Spring Harbor Laboratory Press; all rights reserved; doi: 10.1101/cshperspect.a025551

Cite this article as Cold Spring Harb Perspect Med 2017;7:a025551 


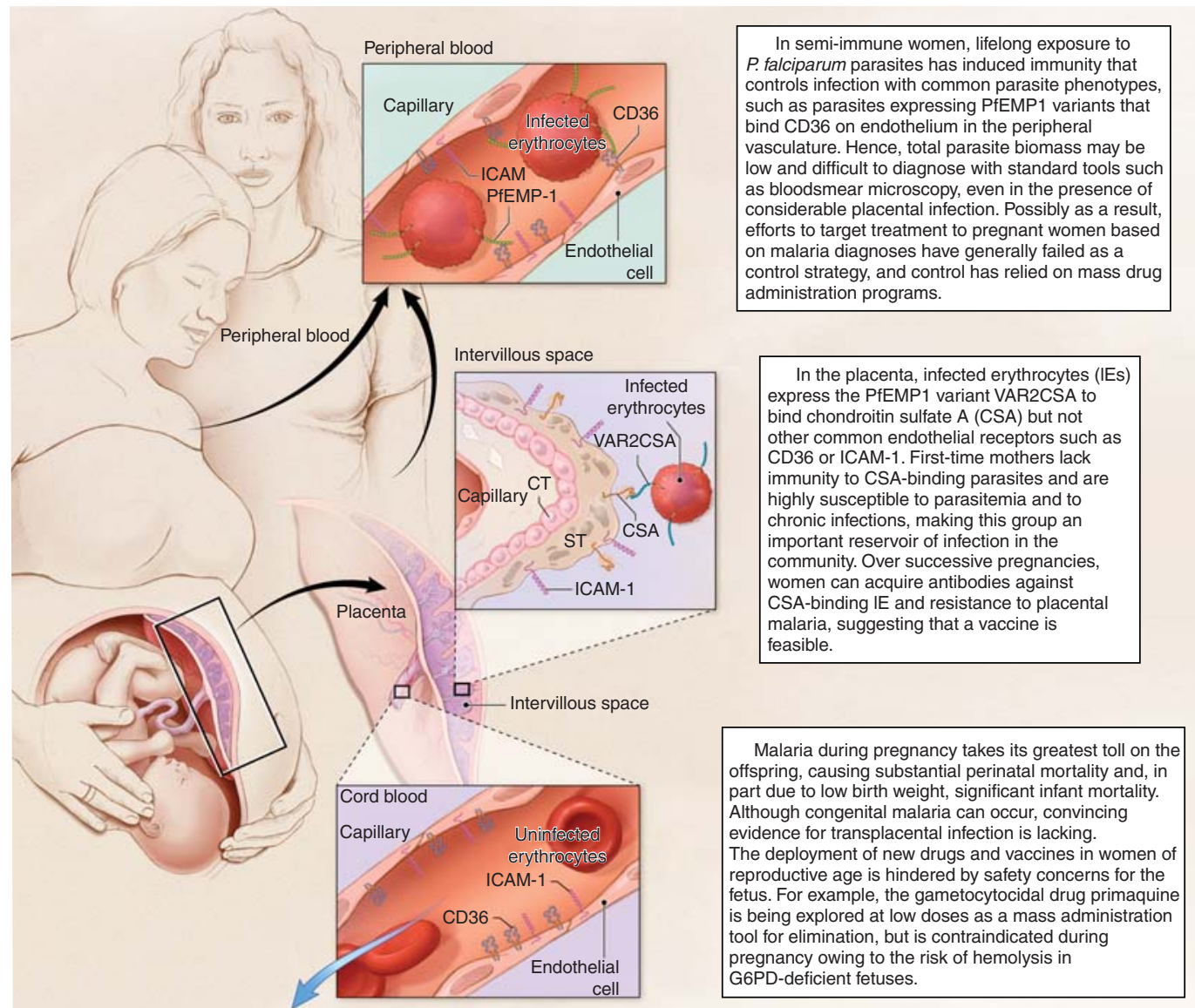

Figure 1. Malaria during pregnancy features several unique host-parasite interactions that require special attention for elimination strategies. Although malaria is more common in pregnant women than other adults, it is difficult to diagnose and therefore to control. The few drugs known to be safe during pregnancy are losing efficacy to drug-resistant Plasmodium falciparum parasites, and the use of new drugs or other interventions is hindered by concerns for fetal safety. Based on the knowledge of malaria immunity during pregnancy, vaccine approaches appear promising for the control of PM, but first-generation candidates are only now entering clinical trials and it is unclear whether these products will interrupt malaria transmission in pregnant women.

considered for prevention and treatment, to envision future approaches for malaria elimination that might be applied to women who may be pregnant.

\section{EPIDEMIOLOGY AND BURDEN OF DISEASE}

Pregnancy malaria looks very different in areas of low and unstable transmission versus high and stable transmission, although overall disease burden in different transmission zones may be similarly heavy in the absence of preventive measures. Where malaria transmission is low and unstable, women are infected infrequently but therefore have low immunity and often rapidly progress to severe disease syndromes when infected. These women have higher risks of severe malaria and death than their nonpregnant counterparts during $P$. falciparum infection (Duffy and Desowitz 2001) and are more likely to develop syndromes like respiratory distress and cerebral malaria (Nosten et al. 1991). In low transmission areas, women of all parities have increased susceptibility to malaria (Nosten et al. 
1991). Women in these areas should be routinely screened and promptly treated for infection to prevent the risk of severe disease and death.

In areas of stable $P$. falciparum malaria transmission, where approximately 50 million pregnancies occur each year, women are semiimmune and often carry their infections with few or no symptoms. Disease for mother and offspring often develops as an insidious process, and this can make it difficult to relate outcomes such as severe maternal anemia or low birth weight (LBW) back to the infection that caused these sequelae. In areas of stable transmission, primigravid women are at greatest risk, and over successive pregnancies women naturally acquire resistance to $P$. falciparum that reduces parasite density and prevents disease. Resistance has been associated with antibodies against the parasitized red cells that bind chondroitin sulfate A (CSA) in the placenta (Fried et al. 1998a). In communities in which malaria control has improved and the incidence of malaria decreases, the incidence of $P$. falciparum pregnancy malaria also decreases, but malaria-specific antibodies wane and the parasite burden and sequelae during any individual infection increase (Mayor et al. 2015).

In areas of stable transmission, interventional studies have provided evidence to estimate the burden of disease. Chemoprophylaxis with pyrimethamine/dapsone (Maloprim) in The Gambia provided significant benefits to primigravid (Greenwood et al. 1992) and grandmultigravid (parity $>7$ ) women (Greenwood et al. 1989; Menendez et al. 1994): primigravidae on prophylaxis had lower rates of parasitemia and higher hematocrits. The latter is an important effect, because maternal anemia increases risks of LBW, preterm delivery (PTD), perinatal mortality, and neonatal mortality in low- and middle-income countries (Rahman et al. 2016). In a recent meta-analysis, chemoprevention reduced the risk of moderate-to-severe maternal anemia in first- and second-time mothers by $\sim 40 \%$ in malaria-endemic areas (Radeva-Petrova et al. 2014); severe maternal anemia is a major risk factor for maternal mortality when women suffer postpartum hemorrhage, a common event in low-income countries (Tort et al. 2015).
Malaria prevention similarly improves child outcomes, both before and after delivery. In a meta-analysis of interventional trials, relative risk of perinatal mortality when mothers received prevention was 0.73 (95\% CI, 0.530.99) (Garner and Gulmezoglu 2006). Effective prophylaxis reduces the risk of LBW newborns, and LBW is a strong predictor for infant mortality: extrapolating from this reduction in LBW, malaria prevention was estimated to reduce the mortality of neonates born to Gambian primigravidae by $42 \%$, and the postneonatal mortality by $18 \%$ (Greenwood et al. 1992). In an observational birth cohort study, placental malaria (PM) in Tanzanian primigravidae was directly related to increased postneonatal mortality: 9.3\% mortality for offspring of infected first-time mothers, compared with $2.6 \%$ for offspring of uninfected first-time mothers (Duffy and Fried 2011). PM in multigravid women did not significantly increase mortality risk of their offspring. In this community, the population attributable risk percent (PAR\%) of postneonatal infant mortality owing to PM was $29.2 \%$ for first pregnancies.

The direct measurement of postneonatal mortality exceeds the estimates of mortality that would result from LBW, suggesting that other PM-related mechanisms might contribute to infant deaths. Several studies have related $\mathrm{PM}$ to increased risks of malaria infection (Schwarz et al. 2008; Goncalves et al. 2014) and to severe malaria (Goncalves et al. 2014) in offspring during infancy, but this relationship has not been observed in other studies (Awine et al. 2016). Interestingly, PM appears to influence immune responses and milieu in the offspring, which could influence their malaria susceptibility. Fetal sensitization to malaria antigens is common (Fievet et al. 1996; King et al. 2002; Malhotra et al. 2005). Some newborns of infected mothers display a "tolerant" phenotype, and have an increased risk of infection and lower hemoglobin levels during early life (Malhotra et al. 2009). Plasma cytokine levels at birth predict levels measured later during infancy, particularly for interleukin $1 \beta$ (IL-1 $\beta$ ) and tumor necrosis factor $\alpha$ (TNF- $\alpha)$, and also predict the risks of malaria infection and severe 
disease (Kabyemela et al. 2013); however, a relationship between PM and cord cytokine profiles has not been defined. More work is needed to understand whether and how PM in the mother may continue to influence malaria outcomes in her child.

Mixed malaria infections such as $P$. falciparum and Plasmodium vivax might also alter pregnancy malaria outcomes, but many mixed infections appear to be mono-infections when diagnosed by peripheral blood smear (BS). P. vivax, like $P$. falciparum, is associated with poor pregnancy outcomes, but, unlike $P$. falciparum, sequelae may be more common in multigravid pregnancies (reviewed in Duffy 2001). Non-falciparum infections were infrequent and did not appear to impact pregnancy outcomes in West Africa, where P. vivax was absent outside Mali (Williams et al. 2016). In P. vivax-endemic areas, women should be actively screened and treated, but management is complicated because primaquine is contraindicated due to fetal hemolysis risk and, therefore, liver hypnozoite parasite forms remain and cause relapses in the mother.

\section{MOLECULAR PATHOGENESIS}

In stable transmission zones, malaria during pregnancy has a unique epidemiology characterized by parity-dependent susceptibility: primigravid women are infected more frequently and with higher placental parasite densities than multigravid women. A prominent feature of $P$. falciparum malaria during pregnancy is the accumulation of parasites in the placenta, whereas parasite density in the peripheral circulation is low or undetectable (Brabin 1983; McGregor 1984). For decades, the increased susceptibility to malaria during pregnancy was attributed to immunological changes associated with pregnancy, but this could not explain the reduction in infection rate and placental parasite burden over successive pregnancies.

An alternative molecular model to explain parity-dependent susceptibility is based on the ability of $P$. falciparum infected erythrocytes (IEs) to adhere to receptors on the vascular endothelium and thereby sequester in deep vascu- lar beds. During pregnancy, IEs accumulate in the intervillous spaces or bind to the surface of the syncytiotrophoblast in the placenta. In this model, the placenta presents a new receptor for IE adhesion, thereby selecting a parasite subpopulation to which women are naïve before their first pregnancy, making first-time mothers most susceptible. Analyses of the binding profile of placental IE have shown that this parasite subpopulation adheres to placental CSA, and not to CD36, which commonly supports the binding of IE from nonpregnant individuals (Fried and Duffy 1996). With successive pregnancies, women develop specific antibodies to CSA binding and placental IEs that enable them to better control the infection (Fried et al. 1998a); immunoepidemiology studies that support this model are discussed below. Following the identification of CSA as the unique receptor that supports parasite adhesion in the placenta, additional studies conducted at different sites have confirmed this binding phenotype (Fried et al. 1998a, 2006; Beeson et al. 1999; Maubert et al. 2000; Muthusamy et al. 2007).

CSA is a glycosaminoglycan comprising repeats of the disaccharide D-glucoronic acid and $\mathrm{N}$-acetyl-D-galactosamine (GalNAc). CSA is sulfated at the C4 position of GalNAc. The closely related glycosaminoglycans chondroitin sulfate $B$ and chondroitin sulfate $C$ do not support placental IE adhesion. CSA chains vary in their length and degree of sulfation, and further characterization has shown that a low-sulfated CSA (Achur et al. 2000; Alkhalil et al. 2000; Fried et al. 2000; Andrews et al. 2005) of at least six disaccharide repeats (Alkhalil et al. 2000) is optimal to support placental IE adhesion.

IE sequestration in the placenta is followed by the accumulation of macrophages and B cells in the intervillous spaces. The intensity of the inflammatory immune infiltrate varies between women and is inversely related to acquired immunity: macrophages are more commonly observed in placentas from primigravidae who lack specific immunity to placental IE than in those from multigravidae (Garnham 1938; Muehlenbachs et al. 2007).

The cytokine milieu in a healthy uninfected placenta displays a bias toward type 2 cytokines. 
PM leads to marked changes in the cytokine milieu, including increased levels of TNF- $\alpha$, interferon $\gamma($ IFN- $\gamma)$, IL-10, monocyte chemoattractant protein 1 , macrophage inflammatory protein 1 (MIP-1 $\alpha$ and MIP-1 $\beta$ ), CXC ligand 8, CXC ligand 9, and CXC ligand 13 (Fried et al. 1998b; Moormann et al. 1999; Abrams et al. 2003; Chaisavaneeyakorn et al. 2003; Rogerson et al. 2003; Suguitan et al. 2003a,b; Kabyemela et al. 2008; Dong et al. 2012). Increased levels of the cytokines TNF- $\alpha$ and IFN- $\gamma$, and the chemokine CXCL9 that is regulated by IFN- $\gamma$, have been associated with LBW deliveries, especially among primigravid women (Fried et al. 1998b; Rogerson et al. 2003; Kabyemela et al. 2008; Dong et al. 2012). Similarly, transcript levels for the chemokines CXCL13, CXCL9, and CCL18 negatively correlate with birth weight, and up-regulation of IL- 8 and TNF- $\alpha$ transcription in the placenta has been associated with intrauterine growth retardation (Moormann et al. 1999; Muehlenbachs et al. 2007). These studies support but do not prove that these inflammatory mediators contribute to PM sequelae. Animal models that reproduce placental sequestration and inflammation are needed for mechanistic studies to better understand disease pathogenesis.

\section{IMMUNITY AND VACCINES}

\section{Parity-Dependent Acquisition of Antibodies}

The unique epidemiology of pregnancy malaria is characterized by parity-dependent susceptibility. Different approaches to evaluate paritydependent humoral immunity have included serum or plasma reactivity to the IE surface by flow cytometry, adhesion-blocking activity, agglutination of IE, and opsonizing activity (Table 1). Regardless of assay, parity-dependent acquisition of antibody against placental parasites or CSA-binding laboratory isolates has been consistently observed across many studies. Levels of antibodies that surface-react are higher in multigravidae compared with primigravidae in many different countries (Fried et al. 1998a; Ricke et al. 2000; Staalsoe et al. 2001, 2004; Tuikue Ndam et al. 2004; Megnekou et al. 2005; Fievet et al.
2006; Feng et al. 2009; Aitken et al. 2010; Mayor et al. 2011). Adhesion-blocking antibody levels are significantly higher among multigravid than primigravid women (Fried et al. 1998a; O'NeilDunne et al. 2001; Jaworowski et al. 2009; Ndam et al. 2015). Although agglutination of placental parasites is uncommon (Beeson et al. 1999), the proportion of serum samples with agglutinating antibodies was significantly higher among multigravidae than primigravidae (Beeson et al. 1999; Maubert et al. 1999). Similarly, opsonic phagocytosis increased with parity (Keen et al. 2007; Jaworowski et al. 2009). Thus, antibodies to CSA-binding IE or placental parasites provide a robust correlate of parity-dependent resistance, regardless of assay.

\section{Antibodies to Placental Parasites and Infection Status or Infection Risk}

Garnham (1938) described three phases of PM based on histology. In the acute or active infection phase, IE accumulate in the intervillous spaces. In the next phase, now called chronic infection, maternal inflammatory cells accumulate, notably monocytes-macrophages containing malaria pigment (hemozoin). After IE are cleared, parasite pigment remains in the intervillous fibrin, sometimes persisting for months, depending on the parasite burden and corresponding amount of pigment (McGready et al. 2002; Muehlenbachs et al. 2010). This last phase of the infection is referred to as past infection. This chronology of PM is typical for primigravidae, but not for multigravidae who usually clear placental parasites quickly and do not progress beyond the active infection phase. Poor outcomes related to PM, such as LBW and maternal anemia, are most strongly associated with the chronic phase of infection (Ordi et al. 1998; Ismail et al. 2000; Shulman et al. 2001; Muehlenbachs et al. 2010).

The relationship of antibodies to infection status or infection risk has varied between studies (Table 2). This may be due, in part, to the heterogeneous chronology of placental infections, and in part to the effect of infection to boost antibodies. In three of four studies, antiadhesion antibodies have been associated with a 
M. Fried and P.E. Duffy

Table 1. Studies of naturally acquired antiparasite antibodies and parity

\begin{tabular}{|c|c|c|c|c|c|}
\hline $\begin{array}{l}\text { Reference/study } \\
\text { (year) }\end{array}$ & Test & Parasite tested & $\begin{array}{l}\text { Plasma/sera } \\
\text { collected at }\end{array}$ & $n$ & Results \\
\hline Ricke et al. 2000 & $\begin{array}{l}\text { Surface proteins } \\
\text { by flow }\end{array}$ & CSA-selected & Third trimester & $\begin{array}{l}\text { P: } 30 \\
\text { S: } 30 \\
\text { M: } 103\end{array}$ & Increase with parity \\
\hline $\begin{array}{r}\text { Staalsoe et al. } \\
2001,2004\end{array}$ & $\begin{array}{l}\text { Surface proteins } \\
\text { by flow }\end{array}$ & CSA-selected & $\begin{array}{l}\text { Third trimester; } \\
\text { delivery }\end{array}$ & $\begin{array}{l}\text { P: } 78 \\
\text { S: } 105\end{array}$ & Increase with parity \\
\hline $\begin{array}{l}\text { Megnekou et al. } \\
2005\end{array}$ & $\begin{array}{l}\text { Surface proteins } \\
\text { by flow }\end{array}$ & CSA-selected & $\begin{array}{l}\text { Combined second- } \\
\text { third trimesters }\end{array}$ & $\begin{array}{l}\text { P: } 101 \\
\text { S/M: } 114\end{array}$ & Increase with parity \\
\hline Fievet et al. 2006 & $\begin{array}{l}\text { Surface proteins } \\
\text { by flow }\end{array}$ & $\begin{array}{l}\text { Placental } \\
\text { parasites }\end{array}$ & Second trimester & $\begin{array}{l}\text { P: } 62 \\
\text { S: } 50 \\
\text { M: } 153\end{array}$ & Increase with parity \\
\hline Feng et al. 2009 & $\begin{array}{l}\text { Surface proteins } \\
\text { by flow }\end{array}$ & CSA-selected & Second trimester & $\begin{array}{l}\text { P: } 80 \\
\text { S: } 16 \\
\text { M: } 45\end{array}$ & Increase with parity \\
\hline Aitken et al. 2010 & $\begin{array}{l}\text { Surface proteins } \\
\text { by flow }\end{array}$ & CSA-selected & $\begin{array}{l}\text { Second and third } \\
\text { trimesters }\end{array}$ & $\begin{array}{l}\text { P: } 131 \\
\text { S: } 108 \\
\text { M: } 310\end{array}$ & Increase with parity \\
\hline Brolin et al. 2010 & $\begin{array}{l}\text { Surface proteins } \\
\text { by flow }\end{array}$ & CSA-selected & Third trimester & $\begin{array}{l}\text { P: } 189 \\
\text { S: } 21 \\
\text { M: } 72\end{array}$ & Increase with parity \\
\hline Mayor et al. 2011 & $\begin{array}{l}\text { Surface proteins } \\
\text { by flow }\end{array}$ & $\begin{array}{l}\text { CSA-selected, } \\
\text { placental } \\
\text { parasites }\end{array}$ & Delivery & $\begin{array}{l}\text { P: } 30 \\
\text { M: } 60\end{array}$ & $\begin{array}{l}\mathrm{PM}^{-}: \mathrm{M}>\mathrm{P} \\
\mathrm{PM}^{+}: \mathrm{M}>\mathrm{P} \text { for } \\
\quad \text { placental isolates }\end{array}$ \\
\hline Fried et al. 1998a & Anti-adhesion & $\begin{array}{l}\text { Placental } \\
\text { parasites }\end{array}$ & Delivery & $\begin{array}{l}\text { P: } 51 \\
\text { S: } 62 \\
\text { M: } 84\end{array}$ & Increase with parity \\
\hline $\begin{array}{l}\text { O’Neil-Dunne } \\
\text { et al. } 2001\end{array}$ & Anti-adhesion & CSA-selected & During pregnancy & $\begin{array}{l}\text { P: } 45 \\
\text { S/M: } 84\end{array}$ & $\begin{array}{l}\text { Increase with parity } \\
\text { at gestational age } \\
\text { of } 12-20 \mathrm{wk}\end{array}$ \\
\hline $\begin{array}{l}\text { Jaworowski et al. } \\
2009\end{array}$ & Anti-adhesion & CSA-selected & Third trimester & $\begin{array}{l}\text { P: } 44 \\
\text { M: } 29\end{array}$ & Increase with parity \\
\hline $\begin{array}{l}\text { Beeson et al. } \\
1999,2004\end{array}$ & Agglutination & $\begin{array}{l}\text { Placental } \\
\text { parasites }\end{array}$ & Second trimester & $\begin{array}{l}\mathrm{P}: 12 \\
\mathrm{M}: 12\end{array}$ & Increase with parity \\
\hline $\begin{array}{l}\text { Maubert et al. } \\
1999\end{array}$ & Agglutination & $\begin{array}{l}\text { CSA-selected, } \\
\text { placental } \\
\text { parasites }\end{array}$ & Delivery & $\begin{array}{l}\text { P: } 13-76^{\mathrm{a}} \\
\text { M: } 17-143^{\mathrm{a}}\end{array}$ & $\begin{array}{l}\mathrm{PM}^{+}: \text {Increase with } \\
\text { parity for } 2 / 4 \\
\text { isolates }\end{array}$ \\
\hline Keen et al. 2007 & $\begin{array}{l}\text { Opsonizing } \\
\text { activity }\end{array}$ & CSA-selected & Postpartum & $\begin{array}{l}\text { P: } 21 \\
\text { M: } 16\end{array}$ & Increase with parity \\
\hline $\begin{array}{l}\text { Jaworowski et al. } \\
2009\end{array}$ & $\begin{array}{l}\text { Opsonizing } \\
\text { activity }\end{array}$ & CSA-selected & Third trimester & $\begin{array}{l}\text { P: } 44 \\
\text { M: } 29\end{array}$ & Increase with parity \\
\hline Feng et al. 2009 & $\begin{array}{l}\text { Opsonizing } \\
\text { activity }\end{array}$ & CSA-selected & Second trimester & $\begin{array}{l}\text { P: } 80 \\
\text { S: } 16 \\
\text { M: } 45\end{array}$ & Increase with parity \\
\hline
\end{tabular}

Only studies that analyzed more than five subjects per group are included.

P, Primigravidae; S, secundigravidae; $\mathrm{M}$, multigravidae; $\mathrm{PM}^{+}$, malaria-infected; $\mathrm{PM}-$, uninfected; CSA, chondroitin sulfate A.

${ }^{a}$ Number of plasma samples analyzed vary among tested isolates. 
Table 2. Studies of naturally acquired antiparasite antibodies and malaria infection status

\begin{tabular}{|c|c|c|c|c|c|}
\hline $\begin{array}{l}\text { Reference/study } \\
\text { (year) }\end{array}$ & Test & Parasite tested & $\begin{array}{l}\text { Plasma/sera } \\
\text { collected at }\end{array}$ & $n$ & Results \\
\hline $\begin{array}{l}\text { Staalsoe et al. } \\
\quad 2001\end{array}$ & $\begin{array}{l}\text { Surface proteins } \\
\text { by flow }\end{array}$ & CSA-selected & $\begin{array}{l}\text { Third } \\
\text { trimester }\end{array}$ & $\begin{array}{l}\text { P: } 55 \\
\text { M: } 58\end{array}$ & $\begin{array}{l}\text { Multigravid: inverse correlation } \\
\text { between Abs and parasite } \\
\text { density }\end{array}$ \\
\hline $\begin{array}{l}\text { Staalsoe et al. } \\
\quad 2004\end{array}$ & $\begin{array}{l}\text { Surface proteins } \\
\text { by flow }\end{array}$ & CSA-selected & Delivery & All 477 & $\begin{array}{l}\text { Chronic and past infection }> \\
\mathrm{PM}^{-} \text {and acute infection, } \\
\text { regardless of parity }\end{array}$ \\
\hline $\begin{array}{l}\text { Beeson et al. } \\
2004\end{array}$ & $\begin{array}{l}\text { Surface proteins } \\
\text { by flow }\end{array}$ & CSA-selected & Delivery & $\begin{array}{l}\text { P: } 54 \\
\text { M: } 54\end{array}$ & $\begin{array}{l}\text { Primigravid: } \mathrm{PM}^{+}>\mathrm{PM}^{-} \\
\text {Multigravid: no differences }\end{array}$ \\
\hline Elliott et al. 2005 & $\begin{array}{l}\text { Surface proteins } \\
\text { by flow }\end{array}$ & CSA-selected & Delivery & $\begin{array}{l}\text { P: } 46 \\
\text { M: } 20\end{array}$ & $\begin{array}{l}\text { Primigravid: } \mathrm{PM}^{+}>\mathrm{PM}^{-} \text {for } \\
\text { IgG1, IgG3 } \\
\text { Multigravid: no differences }\end{array}$ \\
\hline Ataide et al. 2010 & $\begin{array}{l}\text { Surface proteins } \\
\text { by flow }\end{array}$ & CSA-selected & $\begin{array}{l}\text { Third } \\
\text { trimester }\end{array}$ & P: 268 & Primigravid: $\mathrm{PM}^{+}>\mathrm{PM}^{-}$ \\
\hline Ataide et al. 2011 & $\begin{array}{l}\text { Surface proteins } \\
\text { by flow }\end{array}$ & CSA-selected & $\begin{array}{l}\text { Third } \\
\text { trimester }\end{array}$ & S: 187 & Secundigravid: $\mathrm{PM}^{+}>\mathrm{PM}^{-}$ \\
\hline $\begin{array}{l}\text { Tutterrow et al. } \\
\text { 2012a }\end{array}$ & $\begin{array}{l}\text { Surface proteins } \\
\text { by flow }\end{array}$ & CSA-selected & $\begin{array}{l}\text { Second- } \\
\text { third } \\
\text { trimester }\end{array}$ & Total 27 & $\mathrm{PM}^{-}>\mathrm{PM}^{+}$ \\
\hline $\begin{array}{l}\text { Mayor et al. } \\
\qquad 2011,2013\end{array}$ & $\begin{array}{l}\text { Surface proteins } \\
\text { by flow }\end{array}$ & $\begin{array}{l}\text { Placental } \\
\text { parasites }\end{array}$ & Delivery & Total 293 & $\begin{array}{l}\text { Acute, chronic, and past } \\
\text { infections }>\mathrm{PM}^{-} \text {, regardless } \\
\text { of parity }\end{array}$ \\
\hline Fried et al. 1998 & Anti-adhesion & $\begin{array}{l}\text { Placental } \\
\text { parasites }\end{array}$ & Delivery & $\begin{array}{l}\text { P: } 29 \\
\text { S: } 68 \\
\text { M: } 46\end{array}$ & $\begin{array}{l}\text { Secundigravid: } \mathrm{PM}^{-}>\mathrm{PM}^{+} \\
\text {Primigravid: low activity, no } \\
\text { differences } \\
\text { Multigravid: high activity, no } \\
\text { differences }\end{array}$ \\
\hline $\begin{array}{l}\text { O’Neil-Dunne } \\
\text { et al. } 2001\end{array}$ & Anti-adhesion & CSA-selected & Delivery & Total 97 & $\begin{array}{l}\text { Inverse correlation between Abs } \\
\text { and placental parasite density }\end{array}$ \\
\hline $\begin{array}{l}\text { Beeson et al. } \\
2004\end{array}$ & Anti-adhesion & CSA-selected & Delivery & $\begin{array}{l}\text { P: } 54 \\
\text { M: } 54\end{array}$ & $\begin{array}{l}\text { Primigravid: } \mathrm{PM}^{+}>\mathrm{PM}^{-} \\
\text {Multigravid: no differences }\end{array}$ \\
\hline Ndam et al. 2015 & Anti-adhesion & CSA-selected & Delivery & Total 266 & $\mathrm{PM}^{-}>\mathrm{PM}^{+}$ \\
\hline $\begin{array}{l}\text { Beeson et al. } \\
2004\end{array}$ & Agglutination & $\begin{array}{l}\text { CSA-selected } \\
\text { placental } \\
\text { parasites }\end{array}$ & Delivery & $\begin{array}{l}\mathrm{P}: 54 \\
\mathrm{M}: 54\end{array}$ & $\begin{array}{l}\text { Primigravid and multigravid: } \\
\mathrm{PM}^{+}>\mathrm{PM}^{-}\end{array}$ \\
\hline Ataide et al. 2010 & $\begin{array}{l}\text { Opsonizing } \\
\text { activity }\end{array}$ & CSA-selected & $\begin{array}{l}\text { Third } \\
\text { trimester }\end{array}$ & $P: 268$ & Primigravid: $\mathrm{PM}^{+}>\mathrm{PM}^{-}$ \\
\hline Ataide et al. 2011 & $\begin{array}{l}\text { Opsonizing } \\
\text { activity }\end{array}$ & CSA-selected & $\begin{array}{l}\text { Third } \\
\text { trimester }\end{array}$ & S: 187 & Secundigravid: $\mathrm{PM}^{+}>\mathrm{PM}^{-}$ \\
\hline
\end{tabular}

$\mathrm{PM}^{+}$, Placental malaria positive, defined by the presence of parasites in the placenta; $\mathrm{PM}^{-}$, no parasites or the evidence of past infection by histology; CSA, chondroitin sulfate A. 
M. Fried and P.E. Duffy

reduced risk of infection, or to reduced parasite densities in infected women, supporting a role in protection. Opsonizing activity, agglutinating activity, and IE surface reactivity are elevated during and after an infection, which confounds efforts to assess their relationship with protection against infection. Because naturally acquired immunity to malaria controls infection but does not confer sterile resistance that completely prevents infection, infections also occur in semi-immune multigravidae, and infection boosts their antibody levels (Table 2). As a consequence, increased levels of antibodies, including those that agglutinate, opsonize, or react to the surface of IE, can reflect current or recent exposure to the parasite and thereby confound efforts to find correlates of protection (Ataide et al. 2010).

\section{Immune Responses and Pregnancy Outcomes}

PM commonly leads to severe maternal anemia and LBW deliveries, especially among primigravidae. The association between naturally acquired antibodies and pregnancy outcomes has been seen in some but not all studies, and notably the target population and antibody assay have differed between studies (Table 3). Among Kenyan women with chronic malaria, low serum reactivity to the surface of CSA-binding laboratory IE was associated with lower hemoglobin level and reduced birth weight (Staalsoe et al. 2004). Among 141 malaria-infected women in Malawi (Feng et al. 2009), serum reactivity to the IE surface during the second trimester was lower among the women who presented with anemia (hemoglobin $<11 \mathrm{~g} /$ dL) at the time of delivery (Feng et al. 2009). Opsonic activity among malaria-infected secundigravid women in Malawi was associated with increased birth weight, and opsonic activity was higher among nonanemic than anemic malaria-infected multigravidae (Jaworowski et al. 2009; Ataide et al. 2011). Among Mozambican women who had been infected during pregnancy, high serum reactivity to both placental and children's IE at the time of delivery was associated with increased birth weight and ges- tational age (Mayor et al. 2013). In Kenya, levels of anti-adhesion antibodies to placental IE were associated with increased birth weight and gestational age among offspring of secundigravidae (Duffy and Fried 2003). In Benin, antiadhesion antibodies reduced the likelihood of LBW deliveries (Ndam et al. 2015). Among multigravid women, anti-adhesion antibodies have not been associated with risks of maternal anemia and LBW (Duffy and Fried 2003; Jaworowski et al. 2009), presumably because as a group these women enjoy protective immunity. Together, these studies provide strong support for the idea that antibodies to placental IE confer protection, but do not indicate which antibody effector mechanism(s) is primarily responsible.

\section{PREGNANCY MALARIA VACCINE DEVELOPMENT}

Currently, the leading candidate for a vaccine to prevent pregnancy malaria is VAR2CSA, a member of the var gene or PfEMP1 protein family that is up-regulated in placental parasites as well as CSA-selected laboratory parasites (Salanti et al. 2003; Tuikue Ndam et al. 2005). VAR2CSA is a large protein of $\sim 350 \mathrm{kDa}$ comprising six extracellular Duffy-binding-like (DBL) domains and is too large to manufacture as an intact molecule. Therefore, immunogens being considered for product development incorporate one or a few domains, with or without adjacent interdomain regions.

Several studies compared primigravid to multigravid women for their seroreactivity with different VAR2CSA domains (Table 4). Parity-dependent acquisition of VAR2CSA domain-specific antibody has varied between studies. This could reflect differences in the recombinant proteins based on expression system, allelic variant, or domain boundaries, or differences in study populations such as transmission intensity, gestational age, or prevalence of infection at the time of serum sampling.

Antibody boosting during infection can confound attempts to distinguish between protective antibodies and markers of exposure. Perhaps, for this reason, VAR2CSA antibodies have 
Table 3. Studies of naturally acquired antiparasite antibodies and pregnancy outcomes

Reference/study

(year)

Staalsoe et al. 2004

Beeson et al. 2004

Feng et al. 2009

Aitken et al. 2010

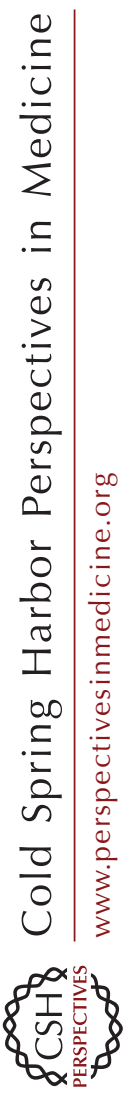

Ataide et al. 2010

Ataide et al. 2011

Mayor et al. 2013

Beeson et al. 2004

Ndam et al. 2015

Beeson et al. 2004

Feng et al. 2009
Serra-Casas et al. 2010 Surface proteins by flow CSA-selected

Duffy and Fried 2003

Anti-adhesion

Jaworowski et al. 2009 Anti-adhesion

Jaworowski et al. 2009 Opsonizing activity

Ataide et al. $2010 \quad$ Opsonizing activity

Ataide et al. $2011 \quad$ Opsonizing activity

parasites

Placental parasites
Parasite tested
Results

Among women with chronic malaria, high IgG associated to increased maternal HGB and BW

No association to BW or maternal HGB

$\mathrm{PM}^{+}$: Abs at weeks $14-26$ associated to decreased maternal anemia $(\mathrm{HGB}<$ $10 \mathrm{~g} / \mathrm{dL}$ )

Surface proteins by flow CSA-selected No association to maternal anemia, BW, and GA

No association to LBW, GA, and maternal anemia

Primigravid: no association to LBW or anemia

Secundigravid $\mathrm{PM}^{+}$: no correlation with BW or maternal HGB

High Abs to placental and child isolates associated to increased BW

Anti-adhesion Abs associated to increased BW, GA

CSA-selected No association to BW or maternal HGB

CSA-selected Multigravid: no association to maternal HGB or BW

CSA-selected Anti-adhesion Abs associated to decreased LBW and SGA

CSA-selected No association to BW or maternal HGB

CSA-selected $\mathrm{PM}^{+}$: Abs at weeks $14-26$ associated to decreased maternal anemia (HGB $<$ $11 \mathrm{~g} / \mathrm{dL})$

CSA-selected Multigravid $\mathrm{PM}^{+}$: lower opsonic activity in anemic $(\mathrm{HGB}<11 \mathrm{~g} / \mathrm{dL})$; no association to BW

CSA-selected Primigravid: no association to LBW or maternal anemia

CSA-selected Secundigravid $\mathrm{PM}^{+}$: correlated with BW

P, Primigravidae; S, secundigravidae; M, multigravidae; CSA, chondroitin sulfate A; $\mathrm{PM}^{+}$, malaria-infected; $\mathrm{PM}^{-}$, uninfected; HGB, hemoglobin; BW, birth weight; LBW, low birth weight; GA, gestational age.

not been related to protection from infection in many studies. After measuring antibody levels to individual DBL domains and domain combinations, Tutterrow et al. (2012a) concluded that antibodies to multiple domains and alleles are needed to reduce PM risk. In Benin, high levels of VAR2CSA-DBL3x antibody during the first two trimesters reduced the risk of PM, although a similar trend was observed with antibody to an unrelated VAR domain (Ndam et al. 2015).

Relationships between VAR2CSA antibodies and pregnancy outcomes have also varied between studies. Among Kenyan women with 
M. Fried and P.E. Duffy

Table 4. Studies of naturally acquired VAR2CSA antibodies and parity

\begin{tabular}{|c|c|c|c|c|}
\hline Domain & $\begin{array}{l}\text { Parity } \\
\text { effect }\end{array}$ & Abs measured at & Study site year, transmission pattern & References \\
\hline \multirow[t]{2}{*}{ DBL1 } & Yes & Delivery & 2001-2005, Muheza-Tanzania, perennial & Oleinikov et al. 2007 \\
\hline & No & Enrollment ${ }^{\mathrm{a}}$ and delivery & 2001, Thiadiaye-Senegal, seasonal & $\begin{array}{l}\text { Tuikue Ndam et al. } \\
2006\end{array}$ \\
\hline $\begin{array}{l}\text { DBL1- } \\
\text { DBL2 }\end{array}$ & Yes & Enrollment ${ }^{\mathrm{a}}$ and delivery & 2008-2010, Comé-Benin, perennial & Ndam et al. 2015 \\
\hline \multirow[t]{2}{*}{ DBL2 } & No & Enrollment ${ }^{\mathrm{a}}$ and delivery & 2001, Thiadiaye-Senegal, seasonal & $\begin{array}{l}\text { Dechavanne et al. } \\
2015\end{array}$ \\
\hline & Yes & Delivery & $\begin{array}{l}\text { 2003-2006, Manhica-Mozambique, } \\
\text { perennial }\end{array}$ & Mayor et al. 2013 \\
\hline ID1-ID2a & No & All trimesters & $\begin{array}{l}\text { 1994-1996 and 2001-2005, Ngali II and } \\
\text { Yaoundé Cameroon, high } \\
\text { transmission and low transmission }\end{array}$ & $\begin{array}{l}\text { Babakhanyan et al. } \\
2014\end{array}$ \\
\hline \multirow[t]{4}{*}{ DBL3 } & Yes & Delivery & $\begin{array}{l}\text { 2001-2005, Muheza-Tanzania, } \\
\text { holoendemic }\end{array}$ & Oleinikov et al. 2007 \\
\hline & & Enrollment ${ }^{\mathrm{a}}$ and delivery & 2008-2010, Comé-Benin, perennial & Ndam et al. 2015 \\
\hline & No & Third trimester & 2000-2002, Blantyre-Malawi, perennial & Brolin et al. 2010 \\
\hline & & Delivery & $\begin{array}{l}\text { 2003-2006, Manhica-Mozambique, } \\
\text { perennial }\end{array}$ & Mayor et al. 2013 \\
\hline \multirow[t]{3}{*}{ DBL4 } & Yes & Delivery & 2008-2010, Comé-Benin, perennial & Ndam et al. 2015 \\
\hline & No & Delivery & 2001-2005, Muheza-Tanzania, perennial & Oleinikov et al. 2007 \\
\hline & & Enrollment $^{\mathrm{a}}$ & 2008-2010, Comé-Benin, perennial & Ndam et al. 2015 \\
\hline \multirow[t]{9}{*}{ DBL5 } & Yes & Delivery & Ghana $^{\mathrm{b}}$, seasonal & Salanti et al. 2004 \\
\hline & & Enrollment $^{\mathrm{a}}$ and delivery & 2001, Thiadiaye-Senegal, seasonal & $\begin{array}{l}\text { Tuikue Ndam et al. } \\
2006\end{array}$ \\
\hline & & Third trimester & 2000-2002, Blantyre-Malawi, perennial & Brolin et al. 2010 \\
\hline & & During pregnancy $^{\mathrm{c}}$ & 2005-2008, Ouidah-Benin, perennial & Gnidehou et al. 2010 \\
\hline & & Delivery & $\begin{array}{l}\text { 2003-2006, Manhica-Mozambique, } \\
\text { perennial }\end{array}$ & Mayor et al. 2013 \\
\hline & & Enrollment $^{\mathrm{a}}$ & 2008-2010, Comé-Benin, perennial & Ndam et al. 2015 \\
\hline & No & Delivery & 2001-2005, Muheza-Tanzania, perennial & Oleinikov et al. 2007 \\
\hline & & Enrollment $^{\mathrm{a}}$ and delivery & 2001, Thiadiaye-Senegal, seasonal & $\begin{array}{l}\text { Dechavanne et al. } \\
2015\end{array}$ \\
\hline & & Delivery & 2008-2010, Comé-Benin, perennial & Ndam et al. 2015 \\
\hline \multirow[t]{5}{*}{ DBL6 } & Yes & Enrollment ${ }^{\mathrm{a}}$ and delivery & 2001, Thiadiaye-Senegal, seasonal & $\begin{array}{l}\text { Tuikue Ndam et al. } \\
2006\end{array}$ \\
\hline & & Delivery & 2001-2005, Muheza-Tanzania, perennial & Oleinikov et al. 2007 \\
\hline & & Delivery & $\begin{array}{l}\text { 2003-2006, Manhica-Mozambique, } \\
\text { perennial }\end{array}$ & Mayor et al. 2013 \\
\hline & No & Third trimester & 2000-2002, Blantyre-Malawi, perennial & Brolin et al. 2010 \\
\hline & & Enrollment $^{\mathrm{a}}$ and delivery & 2001, Thiadiaye-Senegal, seasonal & $\begin{array}{l}\text { Dechavanne et al. } \\
2015\end{array}$ \\
\hline
\end{tabular}

\footnotetext{
${ }^{\text {a}}$ Samples collected at enrollment at any time during the first 6 months of gestation.

${ }^{\mathrm{b}}$ Study year and site information not available.

${ }^{\mathrm{c}}$ Samples collected during pregnancy, but timing not specified.
} 
acute or chronic malaria infection, higher DBL5 antibody levels reduced the risk of LBW delivery (Salanti et al. 2004). Among Mozambican women infected at least once during their pregnancy, above-the-median antibody levels to DBL3X and DBL6e, as well as the unrelated merozoite antigen AMA1, were associated with increased birth weight and gestational age (Mayor et al. 2013). In Benin, high DBL1ID1-DBL2 antibody levels during the first two trimesters reduced the risk of LBW (Ndam et al. 2015). Additional studies that define relationships between specific antibody and protection are needed to advance the development of a vaccine to prevent malaria during pregnancy.

\section{DIAGNOSIS}

Despite its large burden of disease, P. falciparum infection can be difficult to diagnose during pregnancy, particularly in semi-immune women who often are asymptomatic during infection. Although IEs accumulate in the placenta, parasite density in peripheral blood can be too low for detection by routine BS microscopy. BS is the gold standard for malaria diagnosis and is ideal for discriminating the different human malaria parasite species; however, quality varies substantially, and the requirement for microscope and trained microscopist limits BS availability or quality in many places. Paradoxically, although pregnancy malaria is difficult to recognize and diagnose, many women in endemic areas unnecessarily receive antimalarial treatments in the absence of infection. In Mozambique, BS was negative in more than $70 \%$ of pregnant women with clinical symptoms of malaria (Bardaji et al. 2008). Because antimalarials are often prescribed on the basis of clinical and not laboratory criteria, many pregnant women receive unnecessary treatment with drugs that have an unclear safety profile especially in the first trimester.

Rapid diagnostic tests (RDTs) are a more recent tool that is gaining wider acceptance for diagnosis in the general population. RDTs use immunochromatographic approaches to detect soluble Plasmodium antigens, including histidine-rich protein-2 (HRP-2), aldolase, and parasite lactate dehydrogenase ( $\mathrm{pLDH})$. The OptiMAL test, based on PLDH detection, gave varying results when compared with peripheral BS in different studies of pregnant women, with sensitivity ranging from $15 \%$ to $97 \%$ and specificity from $91 \%$ to $98 \%$ (Mankhambo et al. 2002; VanderJagt et al. 2005; Tagbor et al. 2008). The sensitivity of the OptiMAL test increases with parasite density, and all samples with parasite density $<100$ per $\mu$ l were misdiagnosed in one study (VanderJagt et al. 2005). In a larger study (Tagbor et al. 2008), OptiMal had 100\% sensitivity and $93 \%$ specificity for parasite densities $>50$ per $\mu l$ blood, but sensitivity of only $57 \%$ at lower densities. RDTs that detect pLDH have the advantage that they are designed to detect only live parasites; however, gametocytemia in the absence of asexual blood stage parasites can still produce positive results.

In general, RDTs that detect HRP-2 have a higher sensitivity than those that detect pLDH. In one study, RDT-HRP-2 sensitivity was greater than $90 \%$ when compared with peripheral BS, and $80 \%-95 \%$ when compared with placental BS with specificity between $61 \%$ and $94 \%$ (Leke et al. 1999; Mockenhaupt et al. 2002; Singer et al. 2004; Mayor et al. 2012). In a multicenter study in West Africa, RDTs that combine the detection of PLDH and HRP-2 showed similar good sensitivity at some but not all sites (range $63.6 \%-95.1 \%$ in primigravidae) when compared with diagnoses using BS and PCR at first antenatal visits, but not at subsequent visits or at delivery in Ghanaian women $(<60 \%$ sensitivity in all parity groups at delivery) (Williams et al. 2015). In Papua New Guinea, HRP-2/pLDH RDTs were deemed insufficiently sensitive for intermittent screening of asymptomatic anemic women (Umbers et al. 2015). A weakness of RDT-HRP-2 tests is the prolonged half-life of the antigen. HRP-2 can be identified in plasma samples several weeks after parasite clearance, and therefore cannot distinguish current from recent infection (Wongsrichanalai et al. 1999; Mayxay et al. 2001; Tjitra et al. 2001). In Burkina Faso, 2/32 parasitemic pregnant women continued to have detectable HRP-2 antigen $28 \mathrm{~d}$ after receiving artemisinin combination therapy (Kattenberg et al. 2012). These shortcomings 
hinder the use of existing RDTs for managing malaria or monitoring treatment efficacy during pregnancy.

\section{DRUGS FOR PREVENTION AND TREATMENT}

\section{Intermittent Presumptive Treatment (IPTp)}

PM is associated with maternal anemia, LBW deliveries, PTD, and fetal loss. Severe maternal anemia increases the risk of maternal death, and both LBW and PTD increase the risk of infant death. To avoid these poor outcomes, measures to prevent PM have been recommended by the World Health Organization (WHO). The first agent used to prevent PM was weekly choloroquine (CQ) at a prophylaxis dose. However, the emergence of CQ-resistant parasites in subSaharan Africa during the 1980s prompted the search for new strategies. A 1992 study in Malawi showed that two treatment doses of SP given during the second and early third trimester significantly reduced the prevalence of PM compared with CQ (Schultz et al. 1994). A subsequent trial in Kenya confirmed that two SP treatment doses reduced PM prevalence in HIVinfected women (Table 5) (Parise et al. 1998).

In the early 2000s, WHO recommended intermittent presumptive treatment (IPTp) for pregnant women in malaria-endemic regions, with at least two curative doses of the antimalarial drug SP, one dose in the second and the other dose in the third trimester of pregnancy. In 2012, WHO updated the recommendation, increasing the number to three or more SP doses. In practice, women in areas of moderatehigh malaria transmission should receive SP at each antenatal care visit during the second and third trimesters (because four visits are recommended), with 1 mo intervals between doses (www.who.int/malaria/areas/preventive_thera pies/pregnancy/en).

Owing to the spread of SP resistance in subSaharan Africa, artemisinin-based combinations (ACTs) were adopted as the first-line treatment for uncomplicated malaria in the $2000 \mathrm{~s}$ (Eastman and Fidock 2009). Even as the general population was switching to ACT as treatment policy, the IPTp-SP strategy was being widely adopted for pregnant women. At present, WHO continues to recommend IPTp-SP, even in areas with high levels of SP resistance and treatment failure. Here, we summarize studies that have examined the associations between IPTp-SP and malaria parasitemia detected in maternal peripheral blood or placental blood (Table 5). We do not include studies that only reported an association between IPTp-SP and other pregnancy outcomes because the main goal of IPTp-SP is to improve pregnancy outcomes by preventing PM. Improved outcomes without an effect on parasitological measures are difficult to interpret.

During the years 1992-2002, IPTp-SP significantly reduced PM in studies conducted across Africa. However, most data collected after 2001-2002 in East and Southeast Africa indicate that IPTp-SP lost its efficacy to reduce PM prevalence and/or parasite density. This trend has progressed to West Africa, where one site in Ghana reported that IPTp-SP did not reduce PM prevalence (van Spronsen et al. 2012).

SP resistance results from accumulating mutations in $d h f r$ and $d h p s$ genes. The quintuple P. falciparum mutations (three in Pfdhfr and two mutations in Pfdhps) have been associated with treatment failure (Kublin et al. 2002; Naidoo and Roper 2013), and increased placental parasite density with an increasing number of Pfdhfr mutations (Mockenhaupt et al. 2007). A WHO document published in November 2015 (www.who.int/malaria/publications/atoz/istpand-act-in-pregnancy.pdf ) stated that "An association between sextuple mutant haplotypes of $P$. falciparum and decreased birth weight has been reported in observational studies in a few sites in East Africa. Further studies are required to assess this and to devise the best and most cost-effective prevention strategies in areas of very high SP resistance." The policy of continuing IPTp-SP in areas of high resistance is puzzling and inconsistent with WHO directives for malaria treatment (Nosten and McGready 2015), as well as studies that strongly relate $d h f r / d h p s$ mutations to treatment failure.

Currently, IPTp-SP remains efficacious for reducing the rate of $\mathrm{PM}$ and/or parasite burden at some sites in West Africa. However, even in 
Malaria during Pregnancy

M. Fried and P.E. Duffy


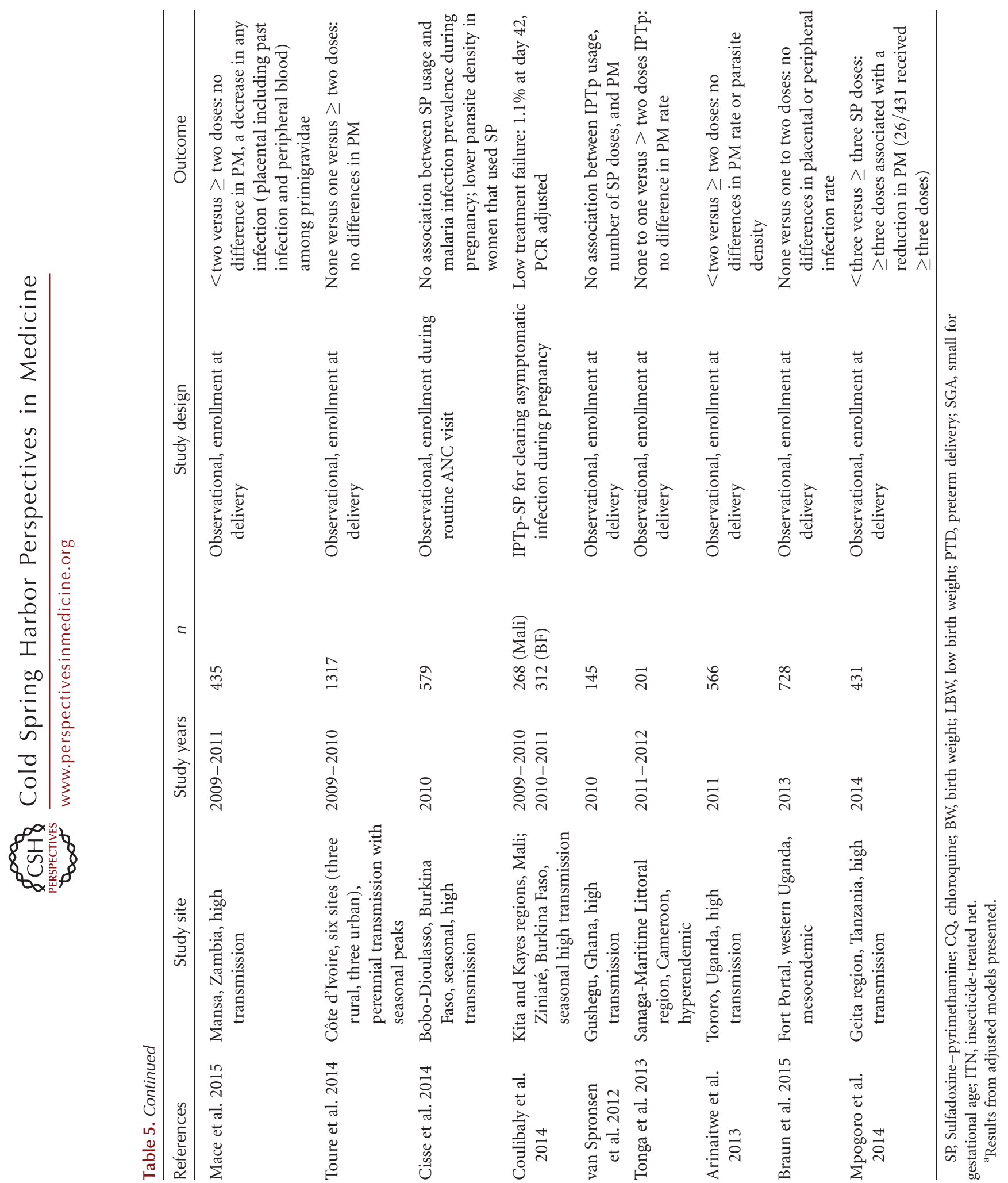
areas with low or moderate SP resistance, the IPTp strategy does not completely prevent PM and the protective effects depend on the timing of the first dose and the interval between treatments (Nosten and McGready 2015).

\section{Alternatives to IPTp-SP \\ Dihydroartemisinin-Piperaquine}

A comparison between three doses of IPTp-SP and three doses or monthly dihydroartemisinin-piperaquine (DP) was recently conducted in Uganda (Kakuru et al. 2016). Peripheral blood parasitemia detected by LAMP was significantly higher in the IPTp-SP group than three doses or monthly DP. Similarly, PM (combined active and past infection) was significantly higher among women who received IPTp-SP than women that received three doses or monthly treatment with DP. Although, among primigravid women, the rate of PM was similar between the three groups, the amount of pigment deposition was significantly higher in the IPTpSP groups, which might indicate higher parasite densities in past infections. The risk of any poor pregnancy outcome (PTD, LBW, congenital anomaly, stillbirth, spontaneous abortion) was significantly lower among women receiving monthly DP than women who received three doses of DP or IPTp-SP.

\section{Mefloquine}

In a comparison of IPTp-SP and IPTp-mefloquine (MQ) (Briand et al. 2009), Beninese women received either two doses of IPTp-SP or two doses of MQ (15 mg/kg) during pregnancy. PM was significantly less frequent in the MQ group, but other endpoints including birth weight, LBW, and maternal anemia were similar (Briand et al. 2009). Adverse events were more common with MQ, and overall tolerability was lower (Briand et al. 2009). Another trial compared two doses of IPTp with SP or MQ in women who also received long-lasting insecticide-treated nets. MQ was given as a single $15 \mathrm{mg} / \mathrm{kg}$ dose or as a split dose (Gonzalez et al. 2014a). The rates of maternal parasitemia (by BS) at delivery, mild anemia at delivery, and clinical malaria during pregnancy were significantly lower in the MQ group, while PM (by BS or histology), birth weight, and LBW rates were similar (Gonzalez et al. 2014a). As in Benin, tolerability was poor even in the group that received MQ as a split dose (Gonzalez et al. 2014a).

IPTp-SP is not recommended for HIV-infected women who take daily cotrimoxazole prophylaxis, owing to the potential adverse effects of taking two antifolate drugs with a common mechanism of action (reviewed in Peters et al. 2007). Two trials evaluated MQ as IPTp in women taking cotrimoxazole (Gonzalez et al. 2014b;). In a multicenter study conducted in East and Southeast Africa, peripheral and placental parasitemia (defined by BS, PCR, or histology) and nonobstetric admission were less frequent among women that received three doses of IPTp-MQ, while maternal anemia, birth weight, and gestational age at delivery were similar between groups (Gonzalez et al. 2014b). Notably, IPTp-MQ was associated with increased mother-to-child transmission of HIV, and again showed poor tolerability (Gonzalez et al. 2014b). In West Africa, IPTp with three MQ doses $(15 \mathrm{mg} / \mathrm{kg}$ ) was compared with cotrimoxazole alone and cotrimoxazole plus IPTp-MQ (Denoeud-Ndam et al. 2014). At delivery, PM was not detected by PCR in any of the 105 women in the cotrimoxazole + IPTpMQ group compared with 5/103 women in the cotrimoxazole alone group. Maternal anemia, infection rate during pregnancy detected by PCR, and birth weight did not differ between groups. Again, adverse events were more common among women receiving MQ (DenoeudNdam et al. 2014). Although MQ can be effective to reduce infection, tolerability has been poor even when used at a split dose, and thus may result in low compliance if used for prevention.

\section{Chloroquine-Azithromycin Combination}

The CQ-azithromycin combination was compared with SP for use as IPTp in a trial that included six sites in Africa. However, interim analyses showed that the new combination was not superior to the existing intervention, and 
the study was terminated early (ClinicalTrials .gov Identifier: NCT01103063).

\section{Intermittent Screening and Treatment}

The Intermittent Screening and Treatment in pregnancy (ISTp) strategy entails screening women for malaria infection during antenatal clinic visits using an RDT and treating infection with an antimalarial drug. A multicenter trial comparing ISTp-AL (artemether-lumefantrine) with IPTp-SP was recently conducted in West Africa in sites with seasonal malaria and low SP resistance (Tagbor et al. 2015). PM, birth weight, and maternal hemoglobin were similar between ISTp-AL and IPTp-SP in the overall analysis and within individual sites (Tagbor et al. 2015). Malaria infections between scheduled visits were significantly more frequent in women randomized to the ISTp-AL (Tagbor et al. 2015). In an area of high malaria transmission and high SP resistance in Kenya, women were randomized to three interventions: ISTp with dihydroartemisinin-piperaquine (DP), IPTp with DP, and IPTp-SP (Desai et al. 2015). Malaria infection at delivery was diagnosed by detection of parasites with BS on peripheral or placental blood, or with RDT or PCR on peripheral blood. Risks of malaria infection, mild anemia (HGB $<11 \mathrm{~g} / \mathrm{dL}$ ), stillbirth, and early infant mortality were significantly reduced in women receiving IPTp-DP rather than IPTp-SP or ISTp-DP, while ISTp-DP and IPTp-SP groups did not differ (Desai et al. 2015). The failure of ISTp-DP to improve on IPTp with the failing drug SP echoes the early evaluation of IPTp-SP in 1992-1994 (Parise et al. 1998) in which case management was inferior to IPTp-SP.

Differences in ISTp efficacy between the two studies could result from different transmission patterns, being highly seasonal in West Africa versus perennial with seasonal peaks in Kenya. Peripheral parasite density at delivery in Kenya was much lower than the density at enrollment in West Africa. Although the different assessment times could influence BS results, lower parasite densities might explain the lower sensitivity of RDT to detect PM, potentially ren- dering the IST strategy ineffective in Kenya (Fried et al. 2012; Desai et al. 2015).

\section{Treatment of Malaria during Pregnancy}

Currently, artemisinin combination therapy (ACT) is the first-line treatment for malaria in nonpregnant individuals. Owing to safety concerns, WHO recommends that pregnant women be treated with quinine and clindamycin during the first trimester and with ACT in the second and third trimesters. A multicenter trial reported high cure rate with four different ACTs (artemether-lumefantrine, amodiaquine-artesunate, dihydroartemisinin-piperaquine, and mefloquine-artesunate), with artemether-lumefantrine showing the lowest cure rate of 94.8\% (The PREGACT Study Group 2016). Pregnancy outcomes were similar between the four groups and both artemether-lumefantrine and dihydroartemisinin-piperaquine had fewer adverse events than amodiaquine-artesunate, and mefloquine-artesunate (The PREGACT Study Group 2016). Analyses of first-trimester antimalarial treatment records at Shoklo Malaria Research Unit in Thailand have shown that artesunate is as safe as choloroquine and quinine (McGready et al. 2012). In a similar study in Kenya, ACT treatment during the first-trimester (based on the review of treatment records) did not increase the risk of miscarriage, compared with women who did not receive any treatment or women who received quinine (Dellicour et al. 2015). However, community surveillance, which included cases without a treatment record, suggested that exposure to ACT may increase the risk of miscarriage compared with women that never received antimalarial drugs (Dellicour et al. 2015). Because both symptomatic and asymptomatic malaria infections (with P. falciparum or P. vivax) during the first trimester increase the risk of miscarriage (McGready et al. 2012), it might be difficult to assess the contribution attributable to ACT when the comparison group includes never-infected women. Both studies had a small number of women that received either ACT or quinine, and clinical trials to compare the safety of ACT to quinine during the first trimester are needed. 
M. Fried and P.E. Duffy

\section{FUTURE PERSPECTIVES}

Pregnant women are at increased risk of malaria, making this demographic group an important parasite reservoir in the community and a key target for interventions during elimination efforts (Fig. 1). However, pregnant women and women of childbearing age will require special considerations during any mass administration campaigns. Semi-immune women often carry P. falciparum PM with low peripheral parasite burdens and few acute symptoms, hindering diagnosis and complicating efforts to use targeted treatment as a strategy. Drugs currently used for malaria prevention during pregnancy have lost or are losing their efficacy, and finding new drugs is stymied by concerns for teratogenicity and embryotoxicity; dihydroartemisinin-piperaquine has shown promise as the monthly presumptive treatment to prevent poor pregnancy outcomes, although it may not reduce PM prevalence. Vaccines have been important tools for the elimination of other infectious pathogens, and women commonly receive vaccines such as tetanus toxoid during pregnancy. Vaccines could be particularly useful for the control of PM: P. falciparum parasites sequester in the human placenta by adhesion to CSA, and women acquire antibodies against CSA-binding parasites over successive pregnancies, rendering primigravidae most susceptible and suggesting a vaccine is feasible. Vaccines that control PM, prevent human infection, or block onward transmission to mosquitoes, will require testing to assess their ability to interrupt transmission through pregnant women. More effort must be made to address the safety of drugs, vaccines, and antivector measures among women of childbearing age, particularly during the first trimester of pregnancy when safety concerns are greatest.

\section{CONCLUDING REMARKS}

Tens of millions of pregnant women are at risk of malaria every year, but the management of malaria is particularly complex in this population. In areas of low transmission, women lacking immunity are at increased risk of acute se- vere disease and of death during $P$. falciparum infection, and therefore active surveillance and prompt treatment of malaria in these women is paramount. In areas of high stable transmission, acquired immunity can mask acute symptoms but leave women vulnerable to insidious effects such as severe maternal anemia and perinatal, neonatal, or postneonatal death for their offspring. Existing diagnostic tools are inadequate to detect malaria infection in semi-immune women, and the drugs CQ and SP used as preventive interventions have lost or are losing their benefits; a replacement drug has yet to be identified that is sufficiently safe, tolerable, and effective as prevention, although studies of dihydroartemisinin-piperaquine are encouraging. Naturally acquired resistance to malaria suggests that vaccines are feasible by inducing antibodies against the CSA-binding parasites that sequester in the human placenta. Passive or active immunization that provides women with a window of coverage throughout pregnancy is an appealing alternative to drug prevention strategies. The need for new preventive and diagnostic tools for this vulnerable population is urgent, but is often overlooked by policymakers and funding agencies. This dearth of safe and effective tools to control malaria in pregnant women will hinder future malaria elimination campaigns, because any woman of childbearing age will likely be excluded from participation if pregnancy status is unknown.

\section{ACKNOWLEDGMENTS}

The authors acknowledge J. Patrick Gorres (Laboratory of Malaria Immunology and Vaccinology, National Institutes of Health $[\mathrm{NIH}]$ ) for proofreading and editing this review, and Alan Hoofring (NIH Medical Arts, NIH) for preparing the illustration. M.F. and P.E.D. are supported by the Intramural Research Program of the National Institute of Allergy and Infectious Diseases (NIAID), NIH.

\section{REFERENCES}

Abrams ET, Brown H, Chensue SW, Turner GD, Tadesse E, Lema VM, Molyneux ME, Rochford R, Meshnick SR, 
Rogerson SJ. 2003. Host response to malaria during pregnancy: Placental monocyte recruitment is associated with elevated $\beta$ chemokine expression. J Immunol 170: 2759 2764.

Achur RN, Valiyaveettil M, Alkhalil A, Ockenhouse CF Gowda DC. 2000. Characterization of proteoglycans of human placenta and identification of unique chondroitin sulfate proteoglycans of the intervillous spaces that mediate the adherence of Plasmodium falciparum-infected erythrocytes to the placenta. J Biol Chem 275: 40344-40356.

Aitken EH, Mbewe B, Luntamo M, Maleta K, Kulmala T, Friso MJ, Fowkes FJ, Beeson JG, Ashorn P, Rogerson SJ. 2010. Antibodies to chondroitin sulfate A-binding infected erythrocytes: Dynamics and protection during pregnancy in women receiving intermittent preventive treatment. J Infect Dis 201: 1316-1325.

Alkhalil A, Achur RN, Valiyaveettil M, Ockenhouse CF, Gowda DC. 2000. Structural requirements for the adherence of Plasmodium falciparum-infected erythrocytes to chondroitin sulfate proteoglycans of human placenta. $J$ Biol Chem 275: 40357-40364.

Andrews KT, Klatt N, Adams Y, Mischnick P, Schwartz-Albiez R. 2005. Inhibition of chondroitin-4-sulfate-specific adhesion of Plasmodium falciparum-infected erythrocytes by sulfated polysaccharides. Infect Immun 73: $4288-4294$.

Arinaitwe E, Ades V, Walakira A, Ninsiima B, Mugagga O, Patil TS, Schwartz A, Kamya MR, Nasr S, Chang M, et al. 2013. Intermittent preventive therapy with sulfadoxinepyrimethamine for malaria in pregnancy: A cross-sectional study from Tororo, Uganda. PLoS ONE 8: e73073.

Ataide R, Hasang W, Wilson DW, Beeson JG, Mwapasa V, Molyneux ME, Meshnick SR, Rogerson SJ. 2010. Using an improved phagocytosis assay to evaluate the effect of HIV on specific antibodies to pregnancy-associated malaria. PLoS ONE 5: e10807.

Ataide R, Mwapasa V, Molyneux ME, Meshnick SR, Rogerson SJ. 2011. Antibodies that induce phagocytosis of malaria infected erythrocytes: Effect of HIV infection and correlation with clinical outcomes. PLoS ONE 6: e22491.

Awine T, Belko MM, Oduro AR, Oyakhirome S, Tagbor H, Chandramohan D, Milligan P, Cairns M, Greenwood B, Williams JE. 2016. The risk of malaria in Ghanaian infants born to women managed in pregnancy with intermittent screening and treatment for malaria or intermittent preventive treatment with sulfadoxine/pyrimethamine. Malaria J 15: 46.

Babakhanyan A, Leke RG, Salanti A, Bobbili N, Gwanmesia P, Leke RJ, Quakyi IA, Chen JJ, Taylor DW. 2014. The antibody response of pregnant Cameroonian women to VAR2CSA ID1-ID2a, a small recombinant protein containing the CSA-binding site. PLoS ONE 9: e88173.

Bardaji A, Sigauque B, Bruni L, Romagosa C, Sanz S, Mabunda S, Mandomando I, Aponte J, Sevene E, Alonso PL, et al. 2008. Clinical malaria in African pregnant women. Malaria J 7: 27.

Beeson JG, Brown GV, Molyneux ME, Mhango C, Dzinjalamala F, Rogerson SJ. 1999. Plasmodium falciparum isolates from infected pregnant women and children are associated with distinct adhesive and antigenic properties. J Infect Dis 180: 464-472.
Beeson JG, Mann EJ, Elliott SR, Lema VM, Tadesse E, Molyneux ME, Brown GV, Rogerson SJ. 2004. Antibodies to variant surface antigens of Plasmodium falciparum-infected erythrocytes and adhesion inhibitory antibodies are associated with placental malaria and have overlapping and distinct targets. J Infect Dis 189: 540-551.

Brabin BJ. 1983. An analysis of malaria in pregnancy in Africa. Bull World Health Org 61: 1005-1016.

Braun V, Rempis E, Schnack A, Decker S, Rubaihayo J, Tumwesigye NM, Theuring S, Harms G, Busingye P, Mockenhaupt FP. 2015. Lack of effect of intermittent preventive treatment for malaria in pregnancy and intense drug resistance in western Uganda. Malaria J 14: 372.

Briand V, Bottero J, Noel H, Masse V, Cordel H, Guerra J, Kossou H, Fayomi B, Ayemonna P, Fievet N, et al. 2009. Intermittent treatment for the prevention of malaria during pregnancy in Benin: A randomized, open-label equivalence trial comparing sulfadoxine-pyrimethamine with mefloquine. J Infect Dis 200: 991-1001.

Brolin KJ, Persson KE, Wahlgren M, Rogerson SJ, Chen Q. 2010. Differential recognition of $P$. falciparum VAR2CSA domains by naturally acquired antibodies in pregnant women from a malaria endemic area. PLoS ONE 5: e9230.

Chaisavaneeyakorn S, Moore JM, Mirel L, Othoro C, Otieno J, Chaiyaroj SC, Shi YP, Nahlen BL, Lal AA, Udhayakumar V. 2003. Levels of macrophage inflammatory protein $1 \alpha$ (MIP-1 $\alpha$ ) and MIP-1 $\beta$ in intervillous blood plasma samples from women with placental malaria and human immunodeficiency virus infection. Clin Diagn Lab Immunol 10: 631-636.

Cisse M, Sangare I, Lougue G, Bamba S, Bayane D, Guiguemde RT. 2014. Prevalence and risk factors for Plasmodium falciparum malaria in pregnant women attending antenatal clinic in Bobo-Dioulasso (Burkina Faso). BMC Infect Dis 14: 631.

Coulibaly SO, Kayentao K, Taylor S, Guirou EA, Khairallah C, Guindo N, Djimde M, Bationo R, Soulama A, Dabira E, et al. 2014. Parasite clearance following treatment with sulphadoxine-pyrimethamine for intermittent preventive treatment in Burkina-Faso and Mali: 42-day in vivo follow-up study. Malaria J 13: 41.

Dechavanne S, Srivastava A, Gangnard S, Nunes-Silva S, Dechavanne C, Fievet N, Deloron P, Chene A, Gamain B. 2015. Parity-dependent recognition of DBL1X-3X suggests an important role of the VAR2CSA high-affinity CSA-binding region in the development of the humoral response against placental malaria. Infect Immun 83: 2466-2474.

Denoeud-Ndam L, Zannou DM, Fourcade C, Taron-Brocard C, Porcher R, Atadokpede F, Komongui DG, Dossou-Gbete L, Afangnihoun A, Ndam NT, et al. 2014. Cotrimoxazole prophylaxis versus mefloquine intermittent preventive treatment to prevent malaria in HIV-infected pregnant women: Two randomized controlled trials. J Acquir Immune Defic Syndr 65: 198-206.

Dellicour S, Tatem AJ, Guerra CA, Snow RW, ter Kuile FO. 2010. Quantifying the number of pregnancies at risk of malaria in 2007: A demographic study. PLoS Med 7: e1000221.

Dellicour S, Desai M, Aol G, Oneko M, Ouma P, Bigogo G, Burton DC, Breiman RF, Hamel MJ, Slutsker L, et al. 2015. Risks of miscarriage and inadvertent exposure to 
M. Fried and P.E. Duffy

artemisinin derivatives in the first trimester of pregnancy: A prospective cohort study in western Kenya. Malaria J 14: 461 .

Desai M, Gutman J, L'Lanziva A, Otieno K, Juma E, Kariuki S, Ouma P, Were V, Laserson K, Katana A, et al. 2015. Intermittent screening and treatment or intermittent preventive treatment with dihydroartemisinin-piperaquine versus intermittent preventive treatment with sulfadoxine-pyrimethamine for the control of malaria during pregnancy in western Kenya: An open-label, three-group, randomised controlled superiority trial. Lancet 386: 2507-2519.

Diakite OS, Kayentao K, Traore BT, Djimde A, Traore B, Diallo M, Ongoiba A, Doumtabe D, Doumbo S, Traore MS, et al. 2011. Superiority of 3 over 2 doses of intermittent preventive treatment with sulfadoxine-pyrimethamine for the prevention of malaria during pregnancy in mali: A randomized controlled trial. Clin Infect Dis 53: 215-223.

Dong S, Kurtis JD, Pond-Tor S, Kabyemela E, Duffy PE, Fried M. 2012. CXC ligand 9 response to malaria during pregnancy is associated with low-birth-weight deliveries. Infect Immun 80: 3034-3038.

Duffy PE. 2001. Immunity to malaria: Different host, different parasite. In Malaria in pregnancy: Deadly parasite, susceptible host (ed. Duffy PE, Fried M), pp. 71-127. Taylor \& Francis, New York.

Duffy PE, Desowitz RS. 2001. Pregnancy malaria throughout history: Dangerous labors. In Malaria in pregnancy: Deadly parasite, susceptible host (ed. Duffy PE, Fried M), pp. 1-25. Taylor \& Francis, New York.

Duffy PE, Fried M. 2003. Antibodies that inhibit Plasmodium falciparum adhesion to chondroitin sulfate A are associated with increased birth weight and the gestational age of newborns. Infect Immun 71: 6620-6623.

Duffy PE, Fried M. 2011. Pregnancy malaria: Cryptic disease, apparent solution. Mem Inst Oswaldo Cruz 106: 64-69.

Eastman RT, Fidock DA. 2009. Artemisinin-based combination therapies: A vital tool in efforts to eliminate malaria. Nat Rev Microbiol 7: 864-874.

Elliott SR, Brennan AK, Beeson JG, Tadesse E, Molyneux ME, Brown GV, Rogerson SJ. 2005. Placental malaria induces variant-specific antibodies of the cytophilic subtypes immunoglobulin G1 (IgG1) and IgG3 that correlate with adhesion inhibitory activity. Infect Immun 73: 5903-5907.

Feng G, Aitken E, Yosaatmadja F, Kalilani L, Meshnick SR, Jaworowski A, Simpson JA, Rogerson SJ. 2009. Antibodies to variant surface antigens of Plasmodium falciparum-infected erythrocytes are associated with protection from treatment failure and the development of anemia in pregnancy. J Infect Dis 200: 299-306.

Feng G, Simpson JA, Chaluluka E, Molyneux ME, Rogerson SJ. 2010. Decreasing burden of malaria in pregnancy in Malawian women and its relationship to use of intermittent preventive therapy or bed nets. PLoS ONE 5: e12012.

Fievet N, Ringwald P, Bickii J, Dubois B, Maubert B, Le Hesran JY, Cot M, Deloron P. 1996. Malaria cellular immune responses in neonates from Cameroon. Parasite Immunol 18: 483-490.
Fievet N, Le Hesran JY, Cottrell G, Doucoure S, Diouf I, Ndiaye JL, Bertin G, Gaye O, Sow S, Deloron P. 2006. Acquisition of antibodies to variant antigens on the surface of Plasmodium falciparum-infected erythrocytes during pregnancy. Infect Genet Evol 6: 459-463.

Fried M, Duffy PE. 1996. Adherence of Plasmodium falciparum to chondroitin sulfate $\mathrm{A}$ in the human placenta. Science 272: 1502-1504.

Fried M, Nosten F, Brockman A, Brabin BJ, Duffy PE. 1998a. Maternal antibodies block malaria. Nature 395: 851-852.

Fried M, Muga RO, Misore AO, Duffy PE. 1998b. Malaria elicits type 1 cytokines in the human placenta: IFN- $\gamma$ and TNF- $\alpha$ associated with pregnancy outcomes. J Immunol 160: $2523-2530$.

Fried M, Lauder RM, Duffy PE. 2000. Plasmodium falciparum: Adhesion of placental isolates modulated by the sulfation characteristics of the glycosaminoglycan receptor. Exp Parasitol 95: 75-78.

Fried M, Domingo GJ, Gowda CD, Mutabingwa TK, Duffy PE. 2006. Plasmodium falciparum: Chondroitin sulfate A is the major receptor for adhesion of parasitized erythrocytes in the placenta. Exp Parasitol 113: 36-42.

Fried M, Muehlenbachs A, Duffy PE. 2012. Diagnosing malaria in pregnancy: An update. Expert Rev Anti Infect Ther 10: $1177-1187$.

Garner P, Gulmezoglu AM. 2006. Drugs for preventing malaria in pregnant women. Cochrane Database Syst Rev doi: 10.1002/14651858.CD000169.pub2.

Garnham PCC. 1938. The placenta in malaria with special reference to reticulo-endothelial immunity. Trans $R$ Soc Trop Med Hyg 32: 13-34.

Gies S, Coulibaly SO, Ky C, Ouattara FT, Brabin BJ, D'Alessandro U. 2009. Community-based promotional campaign to improve uptake of intermittent preventive antimalarial treatment in pregnancy in Burkina Faso. Am J Trop Med Hyg 80: 460-469.

Gnidehou S, Jessen L, Gangnard S, Ermont C, Triqui C, Quiviger M, Guitard J, Lund O, Deloron P, Ndam NT. 2010. Insight into antigenic diversity of VAR2CSADBL5e domain from multiple Plasmodium falciparum placental isolates. PLoS ONE 5: e13105.

Goncalves BP, Huang CY, Morrison R, Holte S, Kabyemela E, Prevots DR, Fried M, Duffy PE. 2014. Parasite burden and severity of malaria in Tanzanian children. $N$ Engl J Med 370: 1799-1808

Gonzalez R, Mombo-Ngoma G, Ouedraogo S, Kakolwa MA, Abdulla S, Accrombessi M, Aponte JJ, AkereyDiop D, Basra A, Briand V, et al. 2014a. Intermittent preventive treatment of malaria in pregnancy with mefloquine in HIV-negative women: A multicentre randomized controlled trial. PLoS Med 11: e1001733.

Gonzalez R, Desai M, Macete E, Ouma P, Kakolwa MA, Abdulla S, Aponte JJ, Bulo H, Kabanywanyi AM, Katana A, et al. 2014b. Intermittent preventive treatment of malaria in pregnancy with mefloquine in HIV-infected women receiving cotrimoxazole prophylaxis: A multicenter randomized placebo-controlled trial. PLoS Med 11: e1001735.

Greenwood BM, Greenwood AM, Snow RW, Byass P, Bennett S, Hatib-N'Jie AB. 1989. The effects of malaria chemoprophylaxis given by traditional birth attendants on 
the course and outcome of pregnancy. Trans $R$ Soc Trop Med Hyg 83: 589-594.

Greenwood AM, Armstrong JR, Byass P, Snow RW, Greenwood BM. 1992. Malaria chemoprophylaxis, birth weight and child survival. Trans R Soc Trop Med Hyg 86: 483485.

Gutman J, Mwandama D, Wiegand RE, Ali D, Mathanga DP, Skarbinski J. 2013. Effectiveness of intermittent preventive treatment with sulfadoxine-pyrimethamine during pregnancy on maternal and birth outcomes in Machinga district, Malawi. J Infect Dis 208: 907-916.

Gutman J, Kalilani L, Taylor S, Zhou Z, Wiegand RE, Thwai KL, Mwandama D, Khairallah C, Madanitsa M, Chaluluka E, et al. 2015. The A581G mutation in the gene encoding Plasmodium falciparum dihydropteroate synthetase reduces the effectiveness of sulfadoxine-pyrimethamine preventive therapy in Malawian pregnant women. J Infect Dis 211: 1997-2005.

Harrington WE, Mutabingwa TK, Muehlenbachs A, Sorensen B, Bolla MC, Fried M, Duffy PE. 2009. Competitive facilitation of drug-resistant Plasmodium falciparum malaria parasites in pregnant women who receive preventive treatment. Proc Natl Acad Sci 106: 9027-9032.

Hommerich L, von Oertzen C, Bedu-Addo G, Holmberg V, Acquah PA, Eggelte TA, Bienzle U, Mockenhaupt FP. 2007. Decline of placental malaria in southern Ghana after the implementation of intermittent preventive treatment in pregnancy. Malaria J 6: 144.

Ismail MR, Ordi J, Menendez C, Ventura PJ, Aponte JJ, Kahigwa E, Hirt R, Cardesa A, Alonso PL. 2000. Placental pathology in malaria: A histological, immunohistochemical, and quantitative study. Hum Pathol 31: 85-93.

Jaworowski A, Fernandes LA, Yosaatmadja F, Feng G, Mwapasa V, Molyneux ME, Meshnick SR, Lewis J, Rogerson SJ. 2009. Relationship between human immunodeficiency virus type 1 coinfection, anemia, and levels and function of antibodies to variant surface antigens in pregnancy-associated malaria. Clin Vaccine Immunol 16: 312319.

Kabyemela ER, Fried M, Kurtis JD, Mutabingwa TK, Duffy PE. 2008. Fetal responses during placental malaria modify the risk of low birth weight. Infect Immun 76: 15271534.

Kabyemela E, Goncalves BP, Prevots DR, Morrison R, Harrington W, Gwamaka M, Kurtis JD, Fried M, Duffy PE. 2013. Cytokine profiles at birth predict malaria severity during infancy. PLoS ONE 8: e77214.

Kakuru A, Jagannathan P, Muhindo MK, Natureeba P, Awori P, Nakalembe M, Opira B, Olwoch P, Ategeka J, Nayebare P, et al. 2016. Dihydroartemisinin-piperaquine for the prevention of malaria in pregnancy. $N$ Engl J Med 374: 928-939.

Kattenberg JH, Tahita CM, Versteeg IA, Tinto H, TraoreCoulibaly M, Schallig HD, Mens PF. 2012. Antigen persistence of rapid diagnostic tests in pregnant women in Nanoro, Burkina Faso, and the implications for the diagnosis of malaria in pregnancy. Trop Med Int Health 17: 550-557.

Keen J, Serghides L, Ayi K, Patel SN, Ayisi J, van Eijk A, Steketee R, Udhayakumar V, Kain KC. 2007. HIV impairs opsonic phagocytic clearance of pregnancy-associated malaria parasites. PLoS Med 4: e181.
King CL, Malhotra I, Wamachi A, Kioko J, Mungai P, Wahab SA, Koech D, Zimmerman P, Ouma J, Kazura JW. 2002. Acquired immune responses to Plasmodium falciparum merozoite surface protein-1 in the human fetus. J Immunol 168: 356-364.

Kublin JG, Dzinjalamala FK, Kamwendo DD, Malkin EM, Cortese JF, Martino LM, Mukadam RA, Rogerson SJ, Lescano AG, Molyneux ME, et al. 2002. Molecular markers for failure of sulfadoxine-pyrimethamine and chlorproguanil-dapsone treatment of Plasmodium falciparum malaria. J Infect Dis 185: 380-388.

Leke RF, Djokam RR, Mbu R, Leke RJ, Fogako J, Megnekou R, Metenou S, Sama G, Zhou Y, Cadigan T, et al. 1999. Detection of the Plasmodium falciparum antigen histidine-rich protein 2 in blood of pregnant women: Implications for diagnosing placental malaria. J Clin Microbiol 37: 2992-2996.

Mace KE, Chalwe V, Katalenich BL, Nambozi M, Mubikayi L, Mulele CK, Wiegand RE, Filler SJ, Kamuliwo M, Craig AS, et al. 2015. Evaluation of sulphadoxine-pyrimethamine for intermittent preventive treatment of malaria in pregnancy: A retrospective birth outcomes study in Mansa, Zambia. Malaria J 14: 69.

Malhotra I, Mungai P, Muchiri E, Ouma J, Sharma S, Kazura JW, King CL. 2005. Distinct Th1- and Th2-Type prenatal cytokine responses to Plasmodium falciparum erythrocyte invasion ligands. Infect Immun 73: 3462-3470.

Malhotra I, Dent A, Mungai P, Wamachi A, Ouma JH, Narum DL, Muchiri E, Tisch DJ, King CL. 2009. Can prenatal malaria exposure produce an immune tolerant phenotype? A-prospective birth cohort study in Kenya. PLoS Med 6: e1000116.

Mankhambo L, Kanjala M, Rudman S, Lema VM, Rogerson SJ. 2002. Evaluation of the OptiMAL rapid antigen test and species-specific PCR to detect placental Plasmodium falciparum infection at delivery. J Clin Microbiol 40: 155158.

Maubert B, Fievet N, Tami G, Cot M, Boudin C, Deloron P. 1999. Development of antibodies against chondroitin sulfate A-adherent Plasmodium falciparum in pregnant women. Infect Immun 67: 5367-5371.

Maubert B, Fievet N, Tami G, Boudin C, Deloron P. 2000. Cytoadherence of Plasmodium falciparum-infected erythrocytes in the human placenta. Parasite Immunol 22: 191-199.

Mayor A, Rovira-Vallbona E, Machevo S, Bassat Q, Aguilar R, Quinto L, Jimenez A, Sigauque B, Dobano C, Kumar S, et al. 2011. Parity and placental infection affect antibody responses against Plasmodium falciparum during pregnancy. Infect Immun 79: 1654-1659.

Mayor A, Moro L, Aguilar R, Bardaji A, Cistero P, SerraCasas E, Sigauque B, Alonso PL, Ordi J, Menendez C. 2012. How hidden can malaria be in pregnant women? Diagnosis by microscopy, placental histology, polymerase chain reaction and detection of histidine-rich protein 2 in plasma. Clin Infect Dis doi: 10.1093/cid/cis236.

Mayor A, Kumar U, Bardaji A, Gupta P, Jimenez A, Hamad A, Sigauque B, Singh B, Quinto L, Kumar S, et al. 2013. Improved pregnancy outcomes in women exposed to malaria with high antibody levels against Plasmodium falciparum. J Infect Dis 207: 1664-1674. 
Mayor A, Bardaji A, Macete E, Nhampossa T, Fonseca AM, Gonzalez R, Maculuve S, Cistero P, Ruperez M, Campo J, et al. 2015. Changing trends in P. falciparum burden, immunity, and disease in pregnancy. $N$ Engl J Med. 373: 1607-1617.

Mayxay M, Pukrittayakamee S, Chotivanich K, Looareesuwan S, White NJ. 2001. Persistence of Plasmodium falciparum HRP-2 in successfully treated acute falciparum malaria. Trans R Soc Trop Med Hyg 95: 179-182.

McGready R, Brockman A, Cho T, Levesque MA, Tkachuk AN, Meshnick SR, Nosten F. 2002. Haemozoin as a marker of placental parasitization. Trans R Soc Trop Med Hyg 96: 644-646.

McGready R, Lee SJ, Wiladphaingern J, Ashley EA, Rijken MJ, Boel M, Simpson JA, Paw MK, Pimanpanarak M, Mu O, et al. 2012. Adverse effects of falciparum and vivax malaria and the safety of antimalarial treatment in early pregnancy: A population-based study. Lancet Infect Dis 12: $388-396$

McGregor IA. 1984. Epidemiology, malaria and pregnancy. Am J Trop Med Hyg 33: 517-525.

Megnekou R, Staalsoe T, Taylor DW, Leke R, Hviid L. 2005. Effects of pregnancy and intensity of Plasmodium falciparum transmission on immunoglobulin G subclass responses to variant surface antigens. Infect Immun 73: 4112-4118.

Menendez C, Todd J, Alonso PL, Lulat S, Francis N, Greenwood BM. 1994. Malaria chemoprophylaxis, infection of the placenta and birth weight in Gambian primigravidae. J Trop Med Hyg 97: 244-248.

Menendez C, Bardaji A, Sigauque B, Romagosa C, Sanz S, Serra-Casas E, Macete E, Berenguera A, David C, Dobano C, et al. 2008. A randomized placebo-controlled trial of intermittent preventive treatment in pregnant women in the context of insecticide treated nets delivered through the antenatal clinic. PLoS ONE 3: e1934.

Mockenhaupt FP, Ulmen U, von Gaertner C, Bedu-Addo G, Bienzle U. 2002. Diagnosis of placental malaria. J Clin Microbiol 40: 306-308.

Mockenhaupt FP, Bedu-Addo G, Junge C, Hommerich L, Eggelte TA, Bienzle U. 2007. Markers of sulfadoxinepyrimethamine-resistant Plasmodium falciparum in placenta and circulation of pregnant women. Antimicrob Agents Chemother 51: 332-334.

Moormann AM, Sullivan AD, Rochford RA, Chensue SW, Bock PJ, Nyirenda T, Meshnick SR. 1999. Malaria and pregnancy: Placental cytokine expression and its relationship to intrauterine growth retardation. J Infect Dis 180: 1987-1993.

Mpogoro FJ, Matovelo D, Dosani A, Ngallaba S, Mugono M, Mazigo HD. 2014. Uptake of intermittent preventive treatment with sulphadoxine-pyrimethamine for malaria during pregnancy and pregnancy outcomes: A crosssectional study in Geita district, North-Western Tanzania. Malaria J 13: 455.

Muehlenbachs A, Fried M, Lachowitzer J, Mutabingwa TK, Duffy PE. 2007. Genome-wide expression analysis of placental malaria reveals features of lymphoid neogenesis during chronic infection. J Immunol 179: 557-565.

Muehlenbachs A, Fried M, McGready R, Harrington WE, Mutabingwa TK, Nosten F, Duffy PE. 2010. A novel histological grading scheme for placental malaria applied in areas of high and low malaria transmission. J Infect Dis 202: $1608-1616$.

Muthusamy A, Achur RN, Valiyaveettil M, Botti JJ, Taylor DW, Leke RF, Gowda DC. 2007. Chondroitin sulfate proteoglycan but not hyaluronic acid is the receptor for the adherence of Plasmodium falciparum-infected erythrocytes in human placenta, and infected red blood cell adherence up-regulates the receptor expression. Am J Pathol 170: $1989-2000$.

Naidoo I, Roper C. 2013. Mapping "partially resistant," “fully resistant," and "super resistant" malaria. Trends Parasitol 29: 505-515.

Ndam NT, Denoeud-Ndam L, Doritchamou J, Viwami F, Salanti A, Nielsen MA, Fievet N, Massougbodji A, Luty AJ, Deloron P. 2015. Protective antibodies against placental malaria and poor outcomes during pregnancy, Benin. Emerg Infect Dis 21: 813-823.

Ndyomugyenyi R, Clarke SE, Hutchison CL, Hansen KS, Magnussen P. 2011. Efficacy of malaria prevention during pregnancy in an area of low and unstable transmission: An individually-randomised placebo-controlled trial using intermittent preventive treatment and insecticidetreated nets in the Kabale Highlands, southwestern Uganda. Trans R Soc Trop Med Hyg 105: 607-616.

Nosten F, McGready R. 2015. Intermittent presumptive treatment in pregnancy with sulfadoxine-pyrimethamine: A counter perspective. Malaria J 14: 248.

Nosten F, ter Kuile F, Maelankirri L, Decludt B, White NJ. 1991. Malaria during pregnancy in an area of unstable endemicity. Trans R Soc Trop Med Hyg 85: 424-429.

Oleinikov AV, Rossnagle E, Francis S, Mutabingwa TK, Fried M, Duffy PE. 2007. Effects of sex, parity, and sequence variation on seroreactivity to candidate pregnancy malaria vaccine antigens. J Infect Dis 196: 155-164.

O'Neil-Dunne I, Achur RN, Agbor-Enoh ST, Valiyaveettil M, Naik RS, Ockenhouse CF, Zhou A, Megnekou R, Leke R, Taylor DW, et al. 2001. Gravidity-dependent production of antibodies that inhibit binding of Plasmodium falciparum-infected erythrocytes to placental chondroitin sulfate proteoglycan during pregnancy. Infect Immun 69: 7487-7492.

Ordi J, Ismail MR, Ventura PJ, Kahigwa E, Hirt R, Cardesa A, Alonso PL, Menendez C. 1998. Massive chronic intervillositis of the placenta associated with malaria infection. Am J Surg Pathol 22: 1006-1011.

Parise ME, Ayisi JG, Nahlen BL, Schultz LJ, Roberts JM, Misore A, Muga R, Oloo AJ, Steketee RW. 1998. Efficacy of sulfadoxine-pyrimethamine for prevention of placental malaria in an area of Kenya with a high prevalence of malaria and human immunodeficiency virus infection. Am J Trop Med Hyg 59: 813-822.

Peters PJ, Thigpen MC, Parise ME, Newman RD. 2007. Safety and toxicity of sulfadoxine/pyrimethamine: Implications for malaria prevention in pregnancy using intermittent preventive treatment. Drug Saf 30: 481-501.

Radeva-Petrova D, Kayentao K, ter Kuile FO, Sinclair D, Garner P. 2014. Drugs for preventing malaria in pregnant women in endemic areas: Any drug regimen versus placebo or no treatment. Cochrane Database Syst Rev 10: CD000169.

Rahman MM, Abe SK, Rahman MS, Kanda M, Narita S, Bilano V, Ota E, Gilmour S, Shibuya K. 2016. Maternal 
anemia and risk of adverse birth and health outcomes in low- and middle-income countries: Systematic review and meta-analysis. Am J Clin Nutr doi: 10.3945/ ajcn.115.107896.

Ricke CH, Staalsoe T, Koram K, Akanmori BD, Riley EM, Theander TG, Hviid L. 2000. Plasma antibodies from malaria-exposed pregnant women recognize variant surface antigens on Plasmodium falciparum-infected erythrocytes in a parity-dependent manner and block parasite adhesion to chondroitin sulfate A. J Immunol 165: 3309-3316.

Rogerson SJ, Brown HC, Pollina E, Abrams ET, Tadesse E, Lema VM, Molyneux ME. 2003. Placental tumor necrosis factor $\alpha$ but not $\gamma$ interferon is associated with placental malaria and low birth weight in Malawian women. Infect Immun 71: 267-270.

Salanti A, Staalsoe T, Lavstsen T, Jensen AT, Sowa MP, Arnot DE, Hviid L, Theander TG. 2003. Selective upregulation of a single distinctly structured var gene in chondroitin sulphate A-adhering Plasmodium falciparum involved in pregnancy-associated malaria. Mol Microbiol 49: 179191.

Salanti A, Dahlback M, Turner L, Nielsen MA, Barfod L, Magistrado P, Jensen AT, Lavstsen T, Ofori MF, Marsh $\mathrm{K}$, et al. 2004. Evidence for the involvement of VAR2CSA in pregnancy-associated malaria. J Exp Med 200: 11971203.

Schultz LJ, Steketee RW, Macheso A, Kazembe P, Chitsulo L, Wirima JJ. 1994. The efficacy of antimalarial regimens containing sulfadoxine-pyrimethamine and/or chloroquine in preventing peripheral and placental Plasmodium falciparum infection among pregnant women in Malawi. Am J Trop Med Hyg 51: 515-522.

Schwarz NG, Adegnika AA, Breitling LP, Gabor J, Agnandji ST, Newman RD, Lell B, Issifou S, Yazdanbakhsh M, Luty AJ, et al. 2008. Placental malaria increases malaria risk in the first 30 months of life. Clin Infect Dis 47: 1017-1025.

Serra-Casas E, Menendez C, Bardaji A, Quinto L, Dobano C, Sigauque B, Jimenez A, Mandomando I, Chauhan VS, Chitnis CE, et al. 2010. The effect of intermittent preventive treatment during pregnancy on malarial antibodies depends on HIV status and is not associated with poor delivery outcomes. J Infect Dis 201: 123-131.

Shulman CE, Dorman EK, Cutts F, Kawuondo K, Bulmer JN, Peshu N, Marsh K. 1999. Intermittent sulphadoxinepyrimethamine to prevent severe anaemia secondary to malaria in pregnancy: A randomised placebo-controlled trial. Lancet 353: 632-636.

Shulman CE, Marshall T, Dorman EK, Bulmer JN, Cutts F, Peshu N, Marsh K. 2001. Malaria in pregnancy: Adverse effects on haemoglobin levels and birthweight in primigravidae and multigravidae. Trop Med Int Health 6: 770778.

Singer LM, Newman RD, Diarra A, Moran AC, Huber CS, Stennies G, Sirima SB, Konate A, Yameogo M, Sawadogo $\mathrm{R}$, et al. 2004. Evaluation of a malaria rapid diagnostic test for assessing the burden of malaria during pregnancy. Am J Trop Med Hyg 70: 481-485.

Staalsoe T, Megnekou R, Fievet N, Ricke CH, Zornig HD, Leke R, Taylor DW, Deloron P, Hviid L. 2001. Acquisition and decay of antibodies to pregnancy-associated variant antigens on the surface of Plasmodium falciparum-in- fected erythrocytes that protect against placental parasitemia. J Infect Dis 184: 618-626.

Staalsoe T, Shulman CE, Bulmer JN, Kawuondo K, Marsh K, Hviid L. 2004. Variant surface antigen-specific IgG and protection against clinical consequences of pregnancyassociated Plasmodium falciparum malaria. Lancet 363: 283-289.

Suguitan AL Jr, Cadigan TJ, Nguyen TA, Zhou A, Leke RJ, Metenou S, Thuita L, Megnekou R, Fogako J, Leke RG, et al. 2003a. Malaria-associated cytokine changes in the placenta of women with pre-term deliveries in Yaounde, Cameroon. Am J Trop Med Hyg 69: 574-581.

Suguitan AL Jr, Leke RG, Fouda G, Zhou A, Thuita L, Metenou S, Fogako J, Megnekou R, Taylor DW. 2003b. Changes in the levels of chemokines and cytokines in the placentas of women with Plasmodium falciparum malaria. J Infect Dis 188: 1074-1082.

Tagbor H, Bruce J, Browne E, Greenwood B, Chandramohan D. 2008. Performance of the OptiMAL dipstick in the diagnosis of malaria infection in pregnancy. Ther Clin Risk Manag 4: 631-636.

Tagbor H, Cairns M, Bojang K, Coulibaly SO, Kayentao K, Williams J, Abubakar I, Akor F, Mohammed K, Bationo $\mathrm{R}$, et al. 2015. A non-inferiority, individually randomized trial of intermittent screening and treatment versus intermittent preventive treatment in the control of malaria in pregnancy. PLoS ONE 10: e0132247.

The PREGACT Study Group; Pekyi D, Ampromfi AA, Tinto H, Traore-Coulibaly M, Tahita MC, Valea I, Mwapasa V, Kalilani-Phiri L, Kalanda G, et al. 2016. Four artemisininbased treatments in African pregnant women with Malaria. N Engl J Med 374: 913-927.

Tiono AB, Ouedraogo A, Bougouma EC, Diarra A, Konate AT, Nebie I, Sirima SB. 2009. Placental malaria and low birth weight in pregnant women living in a rural area of Burkina Faso following the use of three preventive treatment regimens. Malaria J 8: 224.

Tjitra E, Suprianto S, McBroom J, Currie BJ, Anstey NM. 2001. Persistent ICT malaria P.f/P.v panmalarial and HRP-2 antigen reactivity after treatment of Plasmodium falciparum malaria is associated with gametocytemia and results in false-positive diagnoses of Plasmodium vivax in convalescence. J Clin Microbiol 39: 1025-1031.

Tonga C, Kimbi HK, Anchang-Kimbi JK, Nyabeyeu HN, Bissemou ZB, Lehman LG. 2013. Malaria risk factors in women on intermittent preventive treatment at delivery and their effects on pregnancy outcome in Sanaga-Maritime, Cameroon. PLoS ONE 8: e65876.

Tort J, Rozenberg P, Traore M, Fournier P, Dumont A. 2015. Factors associated with postpartum hemorrhage maternal death in referral hospitals in Senegal and Mali: A cross-sectional epidemiological survey. BMC Pregnancy Childbirth 15: 235.

Toure OA, Kone PL, Coulibaly MA, Ako BA, Gbessi EA, Coulibaly B, LT NG, Koffi D, Beourou S, Soumahoro A, et al. 2014. Coverage and efficacy of intermittent preventive treatment with sulphadoxine pyrimethamine against malaria in pregnancy in Cote d'Ivoire five years after its implementation. Parasit Vectors 7: 495.

Tuikue Ndam NG, Fievet N, Bertin G, Cottrell G, Gaye A, Deloron P. 2004. Variable adhesion abilities and overlap- 
M. Fried and P.E. Duffy

ping antigenic properties in placental Plasmodium falciparum isolates. J Infect Dis 190: 2001-2009.

Tuikue Ndam NG, Salanti A, Bertin G, Dahlback M, Fievet N, Turner L, Gaye A, Theander T, Deloron P. 2005. High level of var2csa transcription by Plasmodium falciparum isolated from the placenta. J Infect Dis 192: 331-335.

Tuikue Ndam NG, Salanti A, Le-Hesran JY, Cottrell G, Fievet N, Turner L, Sow S, Dangou JM, Theander T, Deloron P. 2006. Dynamics of anti-VAR2CSA immunoglobulin G response in a cohort of Senegalese pregnant women. $J$ Infect Dis 193: 713-720.

Tutterrow YL, Avril M, Singh K, Long CA, Leke RJ, Sama G, Salanti A, Smith JD, Leke RG, Taylor DW. 2012a. High levels of antibodies to multiple domains and strains of VAR2CSA correlate with the absence of placental malaria in Cameroonian women living in an area of high Plasmodium falciparum transmission. Infect Immun 80: 1479-1490.

Tutterrow YL, Salanti A, Avril M, Smith JD, Pagano IS, Ako S, Fogako J, Leke RG, Taylor DW. 2012b. High avidity antibodies to full-length VAR2CSA correlate with absence of placental malaria. PLoS ONE 7: e40049.

Umbers AJ, Unger HW, Rosanas-Urgell A, Wangnapi RA, Kattenberg JH, Jally S, Silim S, Lufele E, Karl S, OmeKaius M, et al. 2015. Accuracy of an HRP-2/panLDH rapid diagnostic test to detect peripheral and placental Plasmodium falciparum infection in Papua New Guinean women with anaemia or suspected malaria. Malaria J 14: 412.

VanderJagt TA, Ikeh EI, Ujah IO, Belmonte J, Glew RH, VanderJagt DJ. 2005. Comparison of the OptiMAL rapid test and microscopy for detection of malaria in pregnant women in Nigeria. Trop Med Int Health 10: 39-41.

Vanga-Bosson HA, Coffie PA, Kanhon S, Sloan C, Kouakou F, Eholie SP, Kone M, Dabis F, Menan H, Ekouevi DK.
2011. Coverage of intermittent prevention treatment with sulphadoxine-pyrimethamine among pregnant women and congenital malaria in Cote d'Ivoire. Malaria J 10: 105.

van Spronsen JH, Schneider TA, Atasige S. 2012. Placental malaria and the relationship to pregnancy outcome at Gushegu District Hospital, Northern Ghana. Trop Doct 42: $80-84$.

Verhoeff FH, Brabin BJ, Chimsuku L, Kazembe P, Russell WB, Broadhead RL. 1998. An evaluation of the effects of intermittent sulfadoxine-pyrimethamine treatment in pregnancy on parasite clearance and risk of low birthweight in rural Malawi. Ann Trop Med Parasitol 92: $141-150$.

Williams JE, Cairns M, Njie F, Laryea Quaye S, Awine T, Oduro A, Tagbor H, Bojang K, Magnussen P, Ter Kuile FO, et al. 2015. The performance of a rapid diagnostic test in detecting malaria infection in pregnant women and the impact of missed infections. Clin Infect Dis doi: $10.1093 / \mathrm{cid} / \mathrm{civ} 1198$.

Williams J, Njie F, Cairns M, Bojang K, Coulibaly SO, Kayentao K, Abubakar I, Akor F, Mohammed K, Bationo R, et al. 2016. Non-falciparum malaria infections in pregnant women in West Africa. Malaria J 15: 53.

Wilson NO, Ceesay FK, Obed SA, Adjei AA, Gyasi RK, Rodney P, Ndjakani Y, Anderson WA, Lucchi NW, Stiles JK. 2011. Intermittent preventive treatment with sulfadoxine-pyrimethamine against malaria and anemia in pregnant women. Am J Trop Med Hyg 85: 12-21.

Wongsrichanalai C, Chuanak N, Tulyayon S, Thanoosingha N, Laoboonchai A, Thimasarn K, Brewer TG, Heppner DG. 1999. Comparison of a rapid field immunochromatographic test to expert microscopy for the detection of Plasmodium falciparum asexual parasitemia in Thailand. Acta Trop 73: 263-273. 


\section{$\&_{\mathrm{CSH}}^{\infty} \&$ Cold Spring Harbor

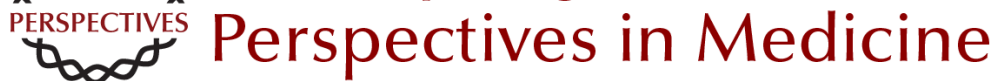

\section{Malaria during Pregnancy}

Michal Fried and Patrick E. Duffy

Cold Spring Harb Perspect Med 2017; doi: 10.1101/cshperspect.a025551 originally published online February 17, 2017

\section{Subject Collection Malaria: Biology in the Era of Eradication}

Modern Vector Control

Neil F. Lobo, Nicole L. Achee, John Greico, et al.

Anopheline Reproductive Biology: Impacts on Vectorial Capacity and Potential Avenues for

Malaria Control Sara N. Mitchell and Flaminia Catteruccia

Current and Future Prospects for Preventing Malaria Transmission via the Use of Insecticides Hilary Ranson

Molecular Signaling Involved in Entry and Exit of Malaria Parasites from Host Erythrocytes Shailja Singh and Chetan E. Chitnis

Vaccines to Accelerate Malaria Elimination and Eventual Eradication Julie Healer, Alan F. Cowman, David C. Kaslow, et al.

Immune Responses in Malaria Carole A. Long and Fidel Zavala

Antimalarial Drug Resistance: A Threat to Malaria Elimination Didier Menard and Arjen Dondorp

Malaria during Pregnancy Michal Fried and Patrick E. Duffy
Malaria Pathogenesis Danny A. Milner, Jr.

Determinants of Malaria Transmission at the Population Level Teun Bousema and Chris Drakeley

\section{Host Cell Tropism and Adaptation of Blood-Stage Malaria Parasites: Challenges for Malaria}

Elimination Caeul Lim, Selasi Dankwa, Aditya S. Paul, et al.

Malaria Transmission and Prospects for Malaria Eradication: The Role of the Environment Marcia C. Castro

The Biology of Plasmodium vivax John H. Adams and Ivo Mueller

Malaria Genomics in the Era of Eradication Daniel E. Neafsey and Sarah K. Volkman

Malaria Epigenetics Alfred Cortés and Kirk W. Deitsch

Malaria Parasite Liver Infection and Exoerythrocytic Biology Ashley M. Vaughan and Stefan H.I. Kappe

For additional articles in this collection, see http://perspectivesinmedicine.cshlp.org/cgi/collection/ 